\title{
Vulnerability, Canadian Disaster LAW, AND THE BEAST
}

\author{
JOCELYN STACEY*
}

\begin{abstract}
This article argues that Canadian law plays a central role in creating and ameliorating conditions of disaster vulnerability. Using the circumstances surrounding the 2016 Fort McMurray wildfire for context, the article identifies and assesses the shared, structural features of Canada's emergency management laws and their application to "natural" disasters. This article argues that these laws lag behind foundational social science research on disasters. It argues that Canadian emergency management laws fail to incorporate a multi-faceted vulnerability perspective, which leaves communities unnecessarily susceptible to disaster harm. This article offers some preliminary suggestions on how Canadian disaster law can begin to integrate a vulnerability perspective to rectify existing gaps and flaws at all stages of the disaster cycle.
\end{abstract}

TABLE OF CONTENTS

I. INTRODUCTION . . . . . . . . . . . . . . . . . . . . . . . . . . . . . 853

II. DEMYSTIFYING DiSASTER LAW $\ldots \ldots \ldots \ldots \ldots \ldots \ldots \ldots \ldots \ldots$

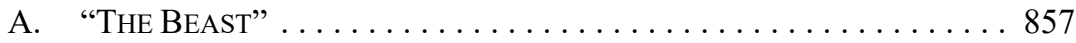

B. ConteXtualizing THE "WiLD" IN WildFire . . . . . . . . . . . . 858

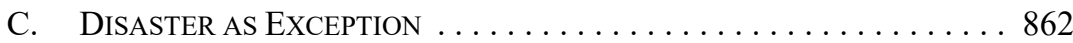

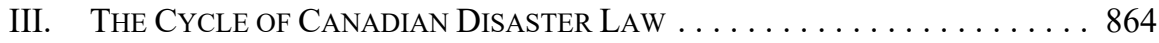

A. The LaW of Disaster PreParedness $\ldots \ldots \ldots \ldots \ldots 65$

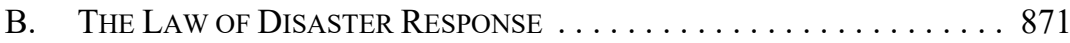

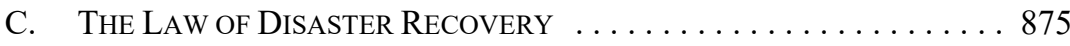

D. The Law of Disaster Prevention ANd Mitigation $\ldots \ldots \ldots . .881$

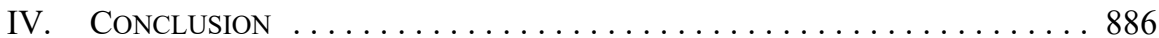

\section{INTRODUCTION}

Disasters cause significant harm to life, livelihood, and property. ${ }^{1}$ Climate change now amplifies background disaster risk by increasing the chance of climate-related extreme events. The Intergovernmental Panel on Climate Change (IPCC) reports that climate change has already impacted "natural and human systems on all continents and across the oceans.".

* Assistant Professor, Allard School of Law, University of British Columbia, Vancouver. Many thanks to my colleagues, Ben Goold and Darlene Johnston, for their helpful feedback on the arguments in this article; to the two anonymous reviewers who provided very thoughtful and constructive comments; and to participants in the "Cities, Planning Law \& the Public Interest" research panel at the Allard School of Law, 12 June 2017. All errors remain my own.

1 The United Nations Office for Disaster Risk Reduction estimates that, between 2005-2014, disasters caused 700,000 deaths, $\$ 1.4$ trillion in damage, and affected 1.7 billion people worldwide: United Nations Office for Disaster Risk Reduction, "The Economic and Human Impact of Disasters in the Last 10 Years," online: <https://www.unisdr.org/we/inform/disaster-statistics>. Disasters can be conceptualized in many different ways. The focus of this article, as will become clear, is on events that were once commonly known as natural disasters (for example, earthquakes, flooding, hurricanes, wildfire) rather than human conflict emergencies (for example, war, terrorist attacks), epidemics, or environmental disasters that are the direct result of man-made hazards (for example, a major oil spill). Intergovernmental Panel on Climate Change, "Summary for Policymakers" in Christopher B Field et al, eds, Climate Change 2014: Impacts, Adaptation, and Vulnerability: Part A: Global and Sectoral Aspects: Contribution of Working Group II to the Fifth Assessment Report of the Intergovernmental Panel on Climate Change (Cambridge: Cambridge University Press, 2014) 1 at 4 [IPCC, "Summary"]. 
It notes, with very high confidence, that ecosystems and human systems are increasingly vulnerable to the impacts of extreme weather: drought, flood, heat waves, and wildfires, for example. ${ }^{3}$ Indeed, what is clear is that climate change has altered and will continue to alter our ecological support systems in serious and potentially irreversible ways. ${ }^{4}$ As a result, people around the globe are subject to the omnipresent threat of climate-related disasters.

As nations go, Canada is comparatively privileged in terms of its affluence, geography, and civic infrastructure. Our northern geography means that we are buffered from the extreme heat experienced, for example, in the Middle East and Australia. ${ }^{5}$ We have an abundance of fresh water, and ample space to relocate should uninhabitable conditions arise due to, for example, rising sea levels. We benefit from first-world physical infrastructure in the vast majority of our cities and towns, ${ }^{6}$ and stable and democratic governments at all levels. Even still, we are vulnerable to climate-related disasters as recent floods, extreme storms, and wildfires demonstrate. ${ }^{7}$

As we will see in more detail below, Canada takes an "all-hazards approach" to regulating emergencies, meaning that federal and provincial laws and policies do not distinguish between "natural" and "human-induced" emergencies. ${ }^{8}$ Rather, legislation, policy frameworks, and central planning documents are developed to apply to all potential hazards, from terrorist attacks to epidemics to flooding. The focus of these laws and policies is on sudden and serious events that require a prompt and coordinated governmental response to protect people and the environment. ${ }^{9}$

While an all-hazards approach undoubtedly avoids potentially problematic and arbitrary distinctions between emergencies, one result is that attention in the legal literature has gravitated toward its implementation with respect to national security crises resulting from

\section{Ibid at 6.}

Ibid at $10,12-13$.

See e.g. Jason Samenow, "Two Middle East Locations Hit 129 Degrees, Hottest Ever in Eastern Hemisphere, Maybe the World," The Washington Post (22 July 2016), online: $<$ https://www.washington post.com/news/capital-weather-gang/wp/2016/07/22/two-middle-east-locations-hit-129-degrees-hottestever-in-eastern-hemisphere-maybe-the-world/>; Penny Timms, "Summer Heat Broke 205 Records and More Extreme Weather is to Come, Climate Council of Australia Reports," ABC News (7 March 2017), online: <www.abc.net.au/news/2017-03-08/summer-heat-part-of-ongoing-extreme-weather-climatecouncil-says/8332740>.

6 An important caveat to this is the condition of many First Nations communities: see e.g. David R Boyd, "No Taps, No Toilets: First Nations and the Constitutional Right to Water in Canada" (2011) 57:1 McGill LJ 81.

7 Canada's Commissioner of the Environment and Sustainable Development has reported that the federal government spent more on disaster recovery between 2009-2015 than in the previous 39 fiscal years combined: Office of the Auditor General of Canada, Spring 2016 Reports of the Commissioner of the Environment and Sustainable Development: Report 2 Mitigating the Impacts of Severe Weather (Ottawa: Office of the Auditor General of Canada, 2016) at exhibit 2.1, online: <www.oag-bvg.gc. ca/internet/English/parl_cesd_201605_02_e_41381.html>.

$8 \quad$ Ministers Responsible for Emergency Management, An Emergency Management Framework for Canada, 3rd ed (Ottawa: Public Safety Canada, 2017) at 3-4, online: <https://www.publicsafety.gc.ca/ $\mathrm{cnt} / \mathrm{rsrcs} / \mathrm{pblctns} / \mathrm{mrgnc}-\mathrm{mngmnt}$-frmwrk/mrgnc-mngmnt-frmwrk-eng.pdf $>$ [EM Framework]. The federal Emergency Management Planning Guide 2010-2011 (Ottawa: Public Safety Canada, 2010), online: $<$ https://www.publicsafety.gc.ca/cnt/rsrcs/pblctns/mrgnc-mngmnt-pnnng/mrgnc-mngmnt-pnnngeng.pdf $>$ [EMP Guide $]$ defines this approach at 60 as:

An approach that recognizes that the actions required to mitigate the effects of emergencies are essentially the same, irrespective of the nature of the event, thereby permitting an optimization of scarce planning, response and support resources. The intention of all-hazards generic emergency planning is to employ generic methodologies, modified as necessary by particular circumstances. EM Framework, ibid at 14, 21 ("disaster" is broadly defined by the seriousness of the harm, and "emergency" is defined by the suddenness and need for government response). 
terrorist threats. Legal literature on national security vastly out scales the nascent attention to disasters. ${ }^{10}$ This article begins to address this inattention to disasters and their regulation by Canadian law. Accordingly, it uses the phrase "disaster law" deliberately to focus in on the specific application of Canadian emergency laws to events such as hurricanes, flooding, wildfire, and earthquakes - in other words, the kinds of events that are commonly called "natural" disasters.

The lack of scholarly attention has left unnoticed major failings in Canadian disaster law to incorporate basic insights from interdisciplinary research on disasters. This article highlights two of these failings. It argues that the current framework of Canadian emergency law lacks nuance in its understanding of vulnerability and fails to identify and address communities that are especially vulnerable to disaster harm. Second, it argues that the implementation of emergency law to disasters fails to adequately incorporate legal mechanisms that can connect disaster law with the underlying drivers of disaster vulnerability. Without attending to these core failings, Canadian disaster law leaves Canadians unnecessarily susceptible to disaster harm.

This article is the first step in a major research project on Canadian disaster law. As a first step, it lays a foundation for this future research by mapping the terrain of the law in Canada that governs disasters. It identifies the structural features of this complex of legal norms that are replicated at each level of government. To provide context for this exercise in mapping, the article focuses on the circumstances surrounding the 2016 Fort McMurray wildfire. As we will see, the Fort McMurray wildfire (the Beast) was a dramatic and extreme event, resulting in the largest prolonged evacuation in Canadian history and requiring a coordinated and sustained emergency response from all levels of government. ${ }^{11}$ As extreme events are predicted to increase in severity and frequency, ${ }^{12}$ a close examination of this wildfire event provides particularly useful insight into the implementation of disaster law at multiple scales.

Focusing on the Beast also allows for a critical examination of the ways in which Canadian disaster law fails to reflect foundational social science research on disaster harm. Notably, the critical dimension of the article is largely focused on identifying what is not included in Canadian disaster law. Namely, it does not incorporate a vulnerability perspective, which has come to be a dominant perspective in interdisciplinary disaster research. This article offers some preliminary suggestions on how Canadian disaster law could integrate basic insights on disaster vulnerability to rectify these gaps. In particular, the article highlights the need for Canadian disaster law to contain - at the very least - a framework that identifies communities that we know are especially vulnerable to disaster harm and provides guidance to decision-makers on how to attend to their vulnerability at all

10 As a very rough estimate of this, a search on WestLaw Next Canada turns up 156 articles on "national security" whereas a search for "natural disaster" returns only two relevant articles. A search of the Hein Online Law Journal Library for "national security" returns 93,609 hits; in contrast, "natural disaster" returns only 7,125. Hurricane Katrina is credited with starting the field of disaster law in the United States: Daniel A Farber et al, eds, Disaster Law and Policy, 3rd ed (New York: Wolters Kluwer, 2015) at $\mathrm{xxi}$.

11 It was deemed the news story of the year by the Canadian press: Lauren Krugel, "Fort McMurray Wildfire Named Canadian Press News Story of 2016," CBC News (20 December 2016), online: $<$ www.cbc.ca/news/canada/edmonton/fort-mcmurray-wildfire-named-canadian-press-news-story-of2016-1.3905042>.

$12 \quad$ IPCC, "Summary," supra note 2 at 12. 
stages of disaster management. It also notes the need for concrete legal tools that explicitly bridge disaster law with other areas of law, such as environmental and land-use planning laws, in order to reduce community vulnerability to future disaster harm.

Part II of this article dispels any doubts about law playing a meaningful role in governing disasters. After introducing the events surrounding the Beast, it offers two hypotheses for the lack of scholarly attention in the legal literature to disaster law. It first addresses the misconception of disasters as "natural" phenomena rather than the products of social conditions that make communities vulnerable to disaster. Second, this part analyzes the deepseated assumption in legal and political theory that law has a limited — or no — role to play during times of emergency. Contrary to these two assumptions, Part II establishes that law is deeply implicated in creating and ameliorating vulnerability to disasters.

Using the Fort McMurray wildfire for context, Part III provides a map of Canadian disaster law, that is, the application of Canada's all-hazards emergency law to the specific subset of emergencies that this article delineates as disasters. Part III outlines the ongoing regulative role that law plays at each stage of disaster preparedness, response, recovery, and prevention. As we will see, certain key legal features are mirrored at each jurisdictional level, creating a thickly-layered body of disaster law.

While Part III evidences the extensive role that law plays in regulating disasters, it also highlights serious gaps in this corpus of law and misalignments between its legal and regulatory requirements and emerging themes on disaster vulnerability from social science research. This part identifies the ways in which Canadian disaster law can begin to integrate a vulnerability perspective to rectify existing gaps and flaws. In particular, it argues that Canadian disaster law requires detailed guidance to decision-makers on how to identify vulnerable communities and how to attend to their specific vulnerabilities to disaster. It points to the glaring inadequacy of the federal government's current approach to emergency management on First Nations' reserves as evidence of this urgent need. It also argues that Canadian disaster law ought to formalize requirements to conduct external post-disaster assessments and integrate disaster risk analysis into existing planning law. It offers these as two examples of preliminary reforms that can link disaster law to underlying drivers of disaster risk. Ultimately, this article shows that we ought to treat the Fort McMurray wildfire as a clear warning. The outcome of the Beast is a best-case scenario in light of Canadian disaster law's current inattention to our ever-present vulnerability to disaster harm.

\section{DEMYSTIFYing Disaster LAW}

This part demystifies disaster law. It addresses possible rationales for the belated study of the law of disasters in Canada - the assumption that disasters are natural and uncontrollable events and the assumption that law plays little or no role in governing emergencies - and it allays any lingering concerns that these pose any real barriers to a critical legal analysis of Canadian disaster law. By the end of this part there should be no doubt that law is deeply implicated in governing disasters. First, however, this part introduces the circumstances of the 2016 Fort McMurray wildfire as this provides essential context for the balance of the article. 


\section{A. "THE BEAST"}

Fort McMurray is an isolated, northern Alberta community, situated in the middle of the sprawling Canadian boreal forest and at the heart of the Alberta oil sands industry. It has a permanent population of approximately 80,000 people. ${ }^{13}$ As the Alberta oil sands industry boomed, so did Fort McMurray's population. Between 2000-2015, the population of the region grew from 51,000 to over $125,000 .{ }^{14}$ During the same period, the "shadow population" of temporary residents ballooned by 580 percent. ${ }^{15}$ Fort McMurray is the main hub in the Regional Municipality of Wood Buffalo, which includes a number of smaller towns, five First Nations communities, and six Métis Locals. ${ }^{16}$

In May of 2016, Fort McMurray and the surrounding region were hit by a devastating wildfire. The fire burned over $5,000 \mathrm{~km}^{2},{ }^{17}$ an area almost equivalent to that of Prince Edward Island. It resulted in the largest prolonged evacuation in Canadian history, ${ }^{18}$ with 88,000 evacuees out of the region's 125,000 residents. ${ }^{19}$ Video footage of the wildfire and the evacuation was gripping. It showed long lines of hundreds of vehicles crawling along a highway flanked by flames while sparks rained down upon the vehicles' rooftops. The fire precipitated an unprecedented amount of private donations to the Canadian Red Cross. ${ }^{20}$ Remarkably, only two people were killed during the wildfire — in a vehicle accident during the evacuation. ${ }^{21}$ And, despite the wildfire ripping right through the city, only 2,400 homes and buildings - or 15 percent of the city's buildings — were destroyed. ${ }^{22}$

The wildfire first triggered a state of local emergency, declared on 1 May $2016 .{ }^{23}$ On 3 May 2016, the fire expanded and rapidly and unexpectedly changed its course. While the municipality had forewarned residents to prepare to evacuate, backyards were on fire before mandatory evacuation orders were issued. ${ }^{24} \mathrm{Within}$ a span of a mere four hours, the majority of residents were ordered to leave. By the night of 3 May 2016, the entire city was under a mandatory evacuation order ${ }^{25}$ and the Athabasca Chipewyan First Nation had also declared a state of local emergency. ${ }^{26}$ The result — the only way to manage such an extensive and urgent evacuation without causing gridlock — was to divide the city in half. ${ }^{27}$ The south of

Regional Municipality of Wood Buffalo, The Municipal Census 2015 Report (RMWB, 2015) at 9, online: <https://www.rmwb.ca/Assets/Corporate/Census+Reports/Municipal+Census+2015+Report. pdf>.

Ibid at 13

Ibid at 15,66 .

Ibid at 81 .

Government of Alberta, Home Again: Recovery after the Wood Buffalo Wildfire (Edmonton: Government of Alberta, 2016) at 4, online: <https://www.alberta.ca/documents/Wildfire-Home-AgainReport.pdf $>$ [Government of Alberta, Home Again].

Ibid at 6 .

Ibid at 4 .

Ibid at 11

Ibid at 6 .

Ibid at 4; KPMG LLP, May 2016 Wood Buffalo Wildfire: Post-Incident Assessment Report (Edmonton: Alberta Emergency Management Agency, 2017) at 14, online: <https://www.alberta.ca/assets/ documents/Wildfire-KPMG-Report.pdf $>$ (reports that 1,958 structures were destroyed).

23 Issued at 10:33 p.m. through Alberta Emergency Alert, "Information Alert Update - Wildfire," online: $<$ www.emergencyalert.alberta.ca/alerts/2016/05/3699.html> ["Wildfire"].

24 Marion Warnica, "Battling the Beast: The Untold Story of the Fight to Save Fort McMurray," CBC News (27 July 2016), online: <www.cbc.ca/interactives/longform/news/battling-the-beast-fortmcmurray-wildfire>.

"Wildfire," supra note 23 at May 3rd 6:49 p.m. and 11:47 p.m.

KPMG LLP, supra note 22 at 26.

Warnica, supra note 24. 
the city evacuated down the only highway to the south, toward Edmonton and Calgary. The northern part of the city had to travel north on the same highway away from any major centres or resources, deeper into the boreal forest. The gamble, fortunately, paid off. Despite the fire moving to the north, northern residents and evacuees remained safe. ${ }^{28}$ On 4 May 2016, the province declared a state of emergency and took the lead over the disaster response. ${ }^{29}$ The provincial state of emergency remained in effect for two months, during which the province's resources were supplemented with those of the Canadian military, Ontario, and South African firefighting personnel. ${ }^{30}$ After extensive (and ongoing) recovery efforts, the majority of residents were able to move back to the city by mid-summer. ${ }^{31}$

\section{B. CONTEXTUALIZING THE "WILD" IN WILDFIRE}

The Beast is a quintessential example of a natural disaster: a fire of extreme proportions that acted in unpredictable ways that experts did not think were possible. For example, it jumped the Athabasca River, a distance of over one kilometre and four times the width of a man-made firebreak. ${ }^{32}$ Tellingly named the Beast, the fire's dynamics were the product of a confluence of environmental factors, such as the unusually high spring temperatures and strong winds blowing the fire toward Fort McMurray. ${ }^{33}$ While experts believe that the immediate trigger of the Beast was human caused, ${ }^{34}$ wildfire is an event that can - and frequently does - occur in the absence of any human influence.

For centuries, events such as wildfires were conceptualized primarily as natural events. Beginning in the Enlightenment era, commentators analyzed the wild and unpredictable behaviour of disasters. ${ }^{35}$ No longer understood as divine intervention (at least not solely), disasters became objects of scientific scrutiny capable of being observed and studied. Scientific fields of seismology and meteorology developed as means to better understand these natural phenomena and mitigate their potential harms. ${ }^{36}$ The study of natural disasters led to the production of sufficient knowledge to develop coordinated response and mitigation efforts. $^{37}$

Scientific analysis of disasters continues to be a vital part of disaster research. But disasters are no longer understood primarily in scientific terms. Across disciplines, the

\section{Ibid.}

OIC 107/2016 (Emergency Management Act).

Government of Alberta, Home Again, supra note 17 at 8.

Ibid at 16.

Warnica, supra note 24.

Paul Roundy, "Why the Effects of 2016 El Niño Trumped Climate Change in the Alberta Wildfires," The Conversation (17 May 2016), online: $<$ https://www.theconversation.com/why-the-effects-of-2016el-nino-trumped-climate-change-in-the-alberta-wildfires-59201>.

Justin Giovannetti, "Fort McMurray Wildfire 'Most Likely Human Caused,' Alberta Senior Wildfire Manager Says," The Globe and Mail (4 June 2016), online: <https://www.theglobeandmail.com/ news/national/fort-mcmurray-wildfire-most-likely-human-caused-alberta-senior-wildfire-managersays/article30279836/>.

35 On the shifting paradigms of disasters from acts of God to acts of nature to acts of man: see Kristian Cedervall Lauta, Disaster Law (Abingdon, UK: Routledge, 2015) at 14ff. See also EL Quarantelli, ed, What is a Disaster?: A Dozen Perspectives on the Question (London: Routledge, 1998); Ronald W Perry, "What is a Disaster?" in Havidán Rodríguez, Enrico L Quarantelli \& Russell R Dynes, eds, Handbook of Disaster Research (New York: Springer, 2007) 1.

$36 \quad$ Lauta, ibid at 19

Ibid. 
predominant conception of disasters is as social phenomena. ${ }^{38}$ That is, while the trigger or hazard may be of natural origin (a wildfire or earthquake), what makes the event a disaster is the community's inability to cope with the event. ${ }^{39} \mathrm{~A}$ wildfire in the middle of the boreal forest may not be a disaster. But a wildfire in the boreal forest bearing down on a remote city of 80,000 people with only one highway out of town has all the makings of a disaster.

One of the most vivid depictions of a "natural" disaster in many North Americans' minds remains Hurricane Katrina, a devastating category five hurricane that destroyed much of New Orleans in 2006. Yet, despite a hurricane being a classic example of a "natural" disaster, commentators have extensively documented the direct effect that social conditions had on the harm suffered as a result of the hurricane. Incautious planning and maintenance of the levees, combined with a slow and confused emergency response, disproportionately affected poor, African-American residents of New Orleans. ${ }^{40}$ Moreover, human caused indirect environmental effects massively increased residents' vulnerability to major storms. The failed levees, for example, built to offer flood protection to the city of New Orleans, also degraded the wetlands along the Gulf by preventing the deposition of sediment from the Mississippi River. ${ }^{41}$ Without this sediment, the wetlands lining the coast collapsed, depriving the coastline of the crucial storm surge protection provided by wetlands' absorptive capacity.

A similar, complex dynamic was at work in the Fort McMurray wildfire disaster with a number of direct and indirect human actions conspiring to increase the likelihood and severity of this extreme event. In particular, the unseasonably high spring temperatures and the lack of precipitation in the preceding 12 months are expected consequences of human caused climate change, exacerbated in 2016 by the effect of El Niño. ${ }^{42}$ Writing about the Lisbon earthquake over 300 years ago, Jean-Jacques Rousseau famously penned: "it was hardly nature that there brought together twenty-thousand houses of six or seven stories."43 Indeed, the same can be said for Fort McMurray: it was hardly nature that built one of Alberta's major urban centres in the middle of the vast boreal forest. ${ }^{44}$

Perhaps lingering notions about disasters being natural phenomena has impeded scholarly legal analysis. When conceptualized as natural phenomena, as events largely outside human control, there is little role for law to play in governing disasters. As natural phenomena, disasters present challenges for science and lend themselves, perhaps, to technological solutions. But, on this view, they cannot be subject to law in any meaningful way.

See Kathleen Tierney, The Social Roots of Risk: Producing Disasters, Promoting Resilience (Stanford: Stanford University Press, 2014); Rasmus Dahlberg, Olivier Rubin \& Morten Thanning Vendelø, eds, Disaster Research: Multidisciplinary and International Perspectives (Abingdon, UK: Routledge, 2016); Michael K Lindell, "Disaster Studies” (2013) 61:5 \& 6 Current Sociology Rev 797.

auta, supra note 35 at 24 . See also Terry Cannon, "Vulnerability Analysis and the Explanation of 'Natural' Disasters" in Ann Varley, ed, Disasters, Development and Environment (Chichester: John Wiley \& Sons, 1994) 13 at 14; Farber et al, supra note 10 at 4. Robert RM Verchick, Facing Catastrophe: Environmental Action for a Post-Katrina World (Cambridge, Mass: Harvard University Press, 2010) at 130, 136-37 [Verchick, Facing Catastrophe]. Daniel Farber, "Symposium Introduction: Navigating the Intersection of Environmental Law and Disaster Law" [2011] 6 BYUL Rev 1783 at 1799-800.

IPCC, "Summary," supra note 2 at 6; Roundy, supra note 33.

Cited in Lauta, supra note 35 at 20.

The wider socio-economic context of the Fort McMurray wildfire came to the fore in the heated discussion about the fire's link to climate change and the link between climate change and the oil sands community: see e.g. Martin Lukacs, "The Arsonists of Fort McMurray Have a Name," The Guardian (12 May 2016), online: <https://www.theguardian.com/environment/true-north/2016/may/12/thearsonists-of-fort-mcmurray-have-a-name $>$. 
Conceptualized as sociological phenomena, however, disasters properly become the subject of law. As leading disaster geographer Terry Cannon writes, "in general, disasters are not natural: they happen to people who are put at risk as a result of their vulnerability." 45 Indeed, this concept of vulnerability is a key concept in interdisciplinary disaster research. ${ }^{46}$ The concept of vulnerability - the susceptibility of individuals, groups, and communities to disaster harm - is particularly useful for a context-sensitive legal analysis of disasters. As I explain now, this is because it has universal, individual, and relational dimensions.

The first conceptual strength of vulnerability is its universality. As human beings, we are all vulnerable, in some way, to harm. ${ }^{47}$ Vulnerability "aris[es] from our embodiment, which carries with it the ever-present possibility of harm, injury, and misfortune. ${ }^{" 48}$ Climate change amplifies this background condition of vulnerability because we are all universally and inescapably subject to the effects of a changing climate, including the possibility of a climate-related disaster.

At the same time, the concept of vulnerability accommodates individual experience. Its sensitivity to individual difference is vulnerability's second conceptual strength. Decades of international experience with disaster harm reduction emphasizes a focus on people rather than generic hazards. The United Nations International Strategy for Disaster Reduction emphasizes the need for "a broader and a more people-centred preventive approach to disaster risk." ${ }^{\prime 49}$ This is because individuals, groups, and communities are vulnerable in vastly different ways. ${ }^{50}$ Empirical research documents the extent to which individual characteristics such as race, gender, ability, and socio-economic status affect vulnerability to disasters. ${ }^{51}$ Even within a relatively affluent and well-equipped community, such as Fort McMurray, individuals are differently vulnerable to a major disaster. While all of Fort McMurray was vulnerable to the Beast, a financially-secure family with extended family in Edmonton was vulnerable in a very different way than a single-income, socially-isolated family facing postdisaster job loss. And these experiences of vulnerability are very different still from an Indigenous member of the community who lost traplines, ceremonial objects, and the temporary ability to hunt and trap in traditional territory. Importantly, social science research

See e.g. W Neil Adger, "Vulnerability" (2006) 16 Global Environmental Change 268; Farber et al, supra note 10, ch 5; Verchick, Facing Catastrophe, supra note 40. Note that in recent years, disaster research has shifted from the concept of vulnerability to its positive foil, resilience: see e.g. Adger, "Vulnerability," ibid; Tierney, supra note 38. As we will see, Canadian disaster law has yet to grapple with vulnerability in any tangible way. Therefore, the focus of this article is necessarily on vulnerability and how law can and ought to incorporate its insights before it can progress from diagnosing the problem (vulnerability) to identifying solutions (resilience).

47 Although the focus of this article is on human vulnerability to disaster harm, note that vulnerability can and is extended to non-human life, including species (for example, the International Union for Conservation of Nature Red List of Threatened Species contains a category for "vulnerable" species: International Union for Conservation of Nature and Natural Resources, "Red List of Threatened Species," online: <www.iucnredlist.org $>$ ).

48 Martha Fineman concisely sets out the case for vulnerability as an animating concept in equality law: Martha Albertson Fineman, "The Vulnerable Subject: Anchoring Equality in the Human Condition" (2008) 20:1 Yale JL \& Feminism 1 at 9.

49 United Nations Office for Disaster Risk Reduction, Sendai Framework for Disaster Risk Reduction 2015-2030 (Geneva: UNODRR, 2015), art 7 [UNISDR, Sendai].

Ibid at 9-10; Lindell, supra note 38 at 799.

51 Susan L Cutter, Bryan J Boruff \& W Lynn Shirley, "Social Vulnerability to Environmental Hazards" (2003) 84:2 Social Science Q 242; Farber et al, supra note 10 at 281. 
on disasters demonstrates that individuals and groups who are marginalized or disadvantaged during ordinary times are those who are most vulnerable to disasters. ${ }^{52}$

Third, vulnerability is relational in the sense that it positions individuals within webs of social and ecological relationships. The UN International Strategy for Disaster Reduction defines vulnerability as "[t]he conditions determined by physical, social, economic, and environmental factors or processes, which increase the susceptibility of a community to the impact of hazards." 53 The IPCC adds that vulnerability to climate-related events is the result of multifaceted, non-climatic factors. ${ }^{54}$ It writes that "heightened vulnerability is ... the product of intersecting social processes that result in inequalities in socioeconomic status and income, as well as in exposure [to adverse effects]." ${ }^{, 5}$ Disaster vulnerability — the intertwining of ecological and social factors - is the vulnerability of place. ${ }^{56}$

The Fort McMurray wildfire illustrates how interconnecting physical and environmental exposure to disasters creates vulnerability. A crown fire, like the Fort McMurray wildfire, will likely cause much greater damage than a surface fire. But social and economic factors also impact vulnerability. A well-coordinated municipal alert system and the ability to access a vehicle, for example, reduce one's vulnerability to disaster.

As a relational concept, vulnerability provides a means by which to analyze the ways in which physical and social interconnections confer advantage and disadvantage that create conditions of vulnerability. ${ }^{57}$ Indeed, disaster research notes that many of the systemic drivers of disaster vulnerability are the same drivers of inequality generally (for example, race and poverty) ${ }^{58}$ Institutional practices such as the provision of universal health care or basic social services and housing, or mandatory environmental assessment that looks for disaster risks before development, all contribute to an individual or group's vulnerability. ${ }^{59}$ Because the state is constituted through these sets of institutional practices and is thus deeply implicated in the conferral of advantages (for example, access to universal health care) and disadvantages (for example, inadequate secure housing), the state bears a responsibility to

52 See especially Ben Wisner et al, eds, At Risk: Natural Hazards, People’s Vulnerability and Disasters, 2nd ed (London: Routledge, 2004) at 4.

53 United Nations Office for Disaster Risk Reduction, Hyogo Framework for Action 2005-2015: Building the Resilience of Nations and Communities to Disasters: Extract from the Final Report of the World Conference on Disaster Reduction (Geneva: UNISDR, 2007) at 1, n 1 [UNISDR, Hyogo]; UNISDR, Sendai, supra note 49 at 10, n 4. In contrast to Canada's all-hazards approach, the UN Strategy for Disaster Reduction addresses "hazards of natural origin and related environmental and technological hazards and risks" (UNISDR, Hyogo, ibid at 1, n 3).

54 IPCC, "Summary," supra note 2 at 6 . See also Adger, "Vulnerability," supra note 46; W Neil Adger, "Social and Ecological Resilience: Are They Related?" (2000) 24:3 Progress in Human Geography 347. IPCC, "Summary," ibid.

Susan Cutter, "The Geography of Social Vulnerability: Race, Class, and Catastrophe" in Understanding Katrina: Perspectives from the Social Sciences (11 June 2006), online: <understandingkatrina. ssrc.org/Cutter/> [Cutter, "Geography"]; Cannon, supra note 39 at 14-15; Robert RM Verchick, "Disaster Justice: The Geography of Human Capability" (2012) 23:1 Duke Envtl L \& Pol'y F 23 at 39 [Verchick, "Disaster Justice"].

$57 \quad$ Fineman, supra note 48 at 16. See also Tierney, supra note 38; Amartya Sen, Resources, Values and Development (Cambridge, Mass: Harvard University Press, 1984).

58 Wisner et al, supra note 52 at 8-10; Cutter, Boruff \& Shirley, supra note 51; Verchick, "Disaster Justice," supra note 56 at 23; Adger, "Vulnerability," supra note 46 at 273. This accords with international experience as well: see UNISDR, Sendai, supra note 49, art 6.

59 Cutter, "Geography," supra note 56. 
address vulnerability. ${ }^{60}$ Vulnerability requires a responsive and responsible state. Nowhere is this expectation clearer than in the aftermath of a disaster. ${ }^{61}$

To sum up, the concept of vulnerability in disaster research is analytically useful because it captures the universal, individual, and relational aspects of disaster harm and response. These features of vulnerability make plain a crucial implication for law: law has an essential role to play in regulating disasters. In a democracy governed under the rule of law, law legitimates the exercise of public authority. Law not only structures, but also legitimates, the institutional practices that create conditions of vulnerability.

\section{DisAster as EXCEPTION}

The misconception of disasters as solely natural phenomena dovetails with a deep-seated assumption in legal and political theory that emergencies are not governable by law. ${ }^{62}$ For example, in his Two Treatises on Government, John Locke theorizes that in ordinary times, government functions are carried out under the rule of law, but that the Crown retains a reserve of prerogative power "to act according to discretion, for the public good, without the prescription of the law, and sometimes even against it." ${ }^{63}$ Emergencies are one scenario Locke foresees in which the legislature will not be able to act, and thus the prerogative or the exercise of executive discretion - will be necessary to respond appropriately. ${ }^{64}$

Emergencies continue to be a perennial focus of political and legal scholarship. Scholarly attention to the state of emergency has surged in the post-9/11 era with an initial focus on the constitutional implications of the "war on terror" 65 and evolving to focus on the permeation of preventive legal measures in the anti-terrorism context. ${ }^{66}$ Much of this conversation about states of emergency has centred on the underlying assumption that law plays little to no role in times of crisis. One constitutional scholar helpfully characterizes the law's role as a toggle switch that flips back and forth between normalcy — governed by ordinary laws and legal requirements — and emergency — governed by a separate legal regime. ${ }^{67}$ Canada's now-

Fineman, supra note 48 at 8-9. Fineman's argument about state responsibility finds further support in theories of republicanism which argue that the state has an obligation to protect individuals from domination: see Philip Pettit, Republicanism: A Theory of Freedom and Government (Oxford: Oxford University Press, 1997); Evan Fox-Decent, Sovereignty's Promise: The State as Fiduciary, (Oxford: Oxford University Press, 2012).

$61 \quad$ Verchick, Facing Catastrophe, supra note 40 at 146.

62 This connection is made in a slightly different way in my earlier work on the theoretical framework of the environmental emergency: Jocelyn Stacey, "The Environmental Emergency and the Legality of Discretion in Environmental Law" (2015) 52:3 Osgoode Hall LJ 985. See also Lauta, supra note 35 at ch 3 .

63 John Locke, Second Treatise of Government (London: Printed for R Butler, 1821) at para 160.

64 Ibid. See also more controversially Carl Schmitt, Political Theology: Four Chapters on the Concept of Sovereignty (Chicago: University of Chicago Press, 1985) at 5-7.

65 For a summary, see Thomas Poole, "Constitutional Exceptionalism and the Common Law" (2009) 7:2 Intl J Constitutional L 247. See also Giorgio Agamben, State of Exception (Chicago: University of Chicago Press, 2005); Bruce Ackerman, Before the Next Attack: Preserving Civil Liberties in an Age of Terrorism (New Haven, Conn: Yale University Press, 2007); Oren Gross, "Chaos and Rules: Should Responses to Violent Crises Always Be Constitutional?" (2003) 112:5 Yale LJ 1011; David Dyzenhaus, The Constitution of Law: Legality in a Time of Emergency (Cambridge, Mass: Cambridge University Press, 2006).

66 See especially Andrew Ashworth \& Lucia Zedner, Preventive Justice (Oxford: Oxford University Press, 2014).

${ }_{67}$ Kim Lane Scheppele, "Small Emergencies" (2006) 40:3 Ga L Rev 835 at 838. See also Oren Gross \& Fionnuala Ní Aoláin, Law in Times of Crisis: Emergency Powers in Theory and Practice (Cambridge, Mass: Cambridge University Press, 2006) ch 1 (on models of accommodation). 
repealed War Measures Act is a good example of the toggle switch in operation. The War Measures Act permitted the executive to declare the existence of an emergency and to take whatever measures were necessary to maintain security, peace, and welfare in Canada. ${ }^{68}$

On this view, law plays a role in governing the emergency, but its focus is narrowly on the trigger for the emergency and its immediate aftermath. The central preoccupation of legal scholars writing about this phenomenon is how law can operate as a constraint on the emergency regime to ensure a polity returns to its normal constitutional order once the emergency has passed. ${ }^{69}$ Perhaps because disasters have not posed a similar threat to destabilizing constitutional order in the common law world, they have not featured in this literature.

To the extent that legal scholarship has moved away from the toggle switch to focus on the increasing juridification of emergency powers, its primary focus has been on the exercise of state power to infringe civil liberties. ${ }^{70}$ With the exception of Hurricane Katrina, disasters and their emergency responses - at least in common law systems - have not posed a significant threat to civil liberties and have not factored into the broader academic conversations about preventive justice. ${ }^{71}$

As a result, the perception of disasters that arises from the existing legal literature is that disasters pose no more than a temporary and exceptional disturbance to the ordinary operation of law. This again may reinforce a misconception that law plays no significant role in regulating disasters.

As we have seen, the concept of disaster vulnerability goes a long way in dispelling this misconception. But it is also important to observe that disasters are not conceived of as temporary and exceptional events in the social science literature on disasters. Rather, they are conceptualized in terms of a "disaster cycle" (or "disaster management cycle" or "risk management cycle"). The disaster cycle captures the idea that the disruption caused by a disaster is only one stage of a continuous, four-stage social and institutional response to any particular extreme event. The disaster cycle's four stages are preparedness, response, recovery, and prevention and mitigation.

Robert Olshansky and Stephanie Chang concisely define these stages in the following way:

Preparedness involves building the capability to respond quickly when a disaster occurs or is imminent.

Response consists of the actions taken at the time of the disaster to save lives and minimise damage. Recovery involves the short-term restoration of lifeline systems and long-term restoration of the community to normal functions. Mitigation consists of activities designed to reduce vulnerability, so as to minimise the deleterious effects of future disasters. ${ }^{72}$

War Measures Act, RSC 1970, c W-2, as repealed by Emergencies Act, RSC 1985, c 22 (4th Supp), s 80. Gross \& Aoláin, supra note 67; Ackerman, supra note 65; Dyzenhaus, supra note 65.

Ashworth \& Zedner, supra note 66 at 1 .

Jocelyn Stacey, "Preventive Justice, the Precautionary Principle and the Rule of Law" in Tulich et al, eds, Regulating Preventive Justice: Principle, Policy and Paradox (Abingdon, UK: Routledge, 2017) 23 at 23 .

Robert Olshansky \& Stephanie Chang, "Planning for Disaster Recovery: Emerging Research Needs and Challenges" (2009) 72:4 Progress in Planning 200 at 200 [emphasis in original]. 
This concept of the disaster cycle dovetails with the focus on vulnerability. Vulnerability and the disaster cycle both presuppose the social paradigm of disasters. The disaster cycle is focused on the community's ability or inability to respond, rather than on the hazard itself. Its four stages reflect the fact that conditions of vulnerability are created and ameliorated long before and can remain long after an extreme event occurs. The disaster cycle responds to this ever-present possibility of harm through a set of continuous social and institutional practices that identify, assess, and ameliorate the risk of disaster harm.

This part has addressed potential concerns that law does not — or cannot - play a meaningful role in regulating disasters. Drawing on mainstream thinking in multidisciplinary disaster research, it has argued that disasters are not solely natural phenomena, but rather sociological phenomena that are usefully understood from the perspective of vulnerability. Vulnerability captures both the environmental and social factors that expose communities to disaster risk. Because disasters ought to be understood through this lens of vulnerability, it becomes clear that the role law plays is an ongoing one, and not a toggle switch that focuses on the extreme event and its immediate aftermath. As we will now see, law also mediates the disaster cycle - or the varied but continuous set of institutional practices that seek to reduce the risk of communities to disaster harm.

\section{The CyCle OF Canadian Disaster LaW}

Having now demonstrated how law plays a significant role in governing disasters, this part turns to the body of law in Canada that can be considered "disaster law." In Canada, constitutional jurisdiction to address disasters falls primarily to the provinces, ${ }^{73}$ which have delegated authority over local emergencies to local governments. As a result, this article does not endeavour to give a comprehensive survey of disaster law across the country. ${ }^{74}$ Rather, it focuses on identifying common structural features of disaster law at each level of government with respect to the Fort McMurray wildfire. We will see that the approach of the federal, provincial, and municipal government has been to adopt a nested structure in which the key legal features of each stage of the disaster law cycle are mirrored at each level of jurisdictional authority. As the scale of the disaster increases, these legal features are engaged at successively higher levels of government.

Canadian law and policy explicitly adopts the four-stage cyclical approach to regulating disasters identified above. However, it uses slightly different nomenclature. The federal government, provinces, and territories have all agreed to an Emergency Management Framework, ${ }^{75}$ which sets out — at a high-level — some common ground for emergency management practices in Canada. The EM Framework draws a distinction between "disaster" and "emergency." It defines disaster as "a social phenomenon that results when a hazard intersects with a vulnerable community in a way that exceeds or overwhelms the community's ability to cope and may cause serious harm to the safety, health, welfare, property or environment of people." " It defines an emergency as "[a] present or imminent

For a summary of provincial emergency legislation, see Craig Forcese, National Security Law: Canadian Practice in International Perspective (Toronto: Irwin Law, 2008) at 360. 
event that requires prompt coordination of actions concerning persons or property to protect the health, safety or welfare of people, or to limit damage to property or the environment."77 Relatedly, it uses the language of "emergency management cycle" to describe the ongoing and iterative set of institutional practices for regulating disasters. ${ }^{78}$ In spite of this legislated terminology, this article maintains that "disaster cycle" is the more appropriate phrase because it reflects the ongoing (that is, not temporary and exceptional) nature of vulnerability emphasized by disaster researchers.

In addition to detailing the legal terrain at each stage in the disaster cycle, this part also argues that Canadian disaster law fails to incorporate a vulnerability perspective. Its failure is apparent in two principal ways: first, Canadian disaster law focuses on generalized hazards rather than attending to vulnerable communities; and second, it adopts an unduly narrow view of the disaster management cycle which fails to link disaster management with systemic drivers of disaster vulnerability. Accordingly, what is absent is equally as important as what is identified in the following description of Canadian disaster law.

\section{A. The Law of Disaster Preparedness}

At each level of government, preparedness is characterized by four central legal features: (1) emergency management legislation, which constitutes (2) an emergency management department; (3) a legally required emergency management plan, which is supported in practice by (4) a government operations centre. While the necessity of comprehensive preparedness to disaster management is clear from these existing legal features, we will see that the law of disaster preparedness focuses on hazards, not people or communities. It thus fails to account for the particular ways in which particular individuals and communities are vulnerable to disaster harm.

\section{FEATURES OF DisAster PREPAREDNESS}

On preparedness, the logical place to begin is with federal jurisdiction, as the federal government has endeavoured to show leadership in emergency preparedness. In this respect, Canada's Emergency Management Act is the framework legislation that sets out the federal government's planning and coordinating obligations. ${ }^{79}$ The EMA (Canada) delegates authority to the federal Minister of Public Safety and Preparedness, who heads Public Safety Canada. Amongst other things, the Minister's preparedness responsibilities include: (1) establishing policies that guide the development, testing, maintenance, and implementation of emergency management plans; (2) "monitoring potential, imminent and actual emergencies"; and (3) supporting and coordinating emergency management initiatives amongst the provinces. ${ }^{80}$ In addition, the EMA (Canada) requires individual ministers to engage in emergency preparedness by identifying risks within their departments, and to

Ibid.

Forcese, supra note 74 at 361 suggests that the difference between disaster and emergency is a matter of timing. As elaborated below, a vulnerability perspective reveals the limitations of separating out the harm (that is, the disaster) from the institutional response (that is, the emergency) reflected in these definitions.

79 SC 2007, c 15 [EMA (Canada)].

80 Ibid, s 4(1). 
prepare, maintain, test, and implement emergency management plans with respect to those risks. $^{81}$

Public Safety Canada has produced an Emergency Management Planning Guide that offers instructions to public institutions on how to prepare an emergency management plan. ${ }^{82}$ The EMP Guide advises that emergency management teams carry out multiple assessments prior to drafting a plan, including: (1) identifying and assessing critical assets and services (for example, critical government buildings and communications); (2) identifying and assessing vulnerabilities of those assets and services and existing safeguards; and (3) identifying, assessing, and evaluating all hazards and risks (for example, wildfire, hazardous material spill, and cyber-attack). ${ }^{83}$

The EMA (Canada) mandates that the federal government maintain multiple emergency management plans: those with respect to the federal government's centralized response to an emergency, and those of individual departments with respect to specific hazards. ${ }^{84}$ The Minister has implemented his preparedness obligations in part through the development of the Federal Emergency Response Plan. ${ }^{85}$ The FERP identifies the circumstances in which an integrated federal emergency response is required, including when a province or territory requests federal support; an emergency affects multiple jurisdictions or federal assets, services, or responsibilities; or "affects other aspects of the national interest." 86

Federal departments must also develop "operational plans" to address the tactical aspects of incident-specific emergency responses. ${ }^{87}$ They must also maintain business continuity plans, which "enable critical services or products to be continually delivered to Canadians in the event of an incident/emergency." ${ }^{88}$ Concerns about transparency arise with respect to emergency planning and preparedness because most of these plans are not publicly available. $^{89}$

Ibid, s 6

EMP Guide, supra note 8.

Ibid at 11-21. The EMP Guide also describes a model governance structure for emergency management (ibid at 23). See also Public Safety Canada, All Hazards Risk Assessment Methodology Guidelines 2012-2013 (Ottawa: PSC, 2012).

84 See e.g. Health Canada, Federal Nuclear Emergency Plan Part I: Master Plan, 5th ed (Ottawa: Health Canada, 2014), online: <https:/www.canada.ca/en/health-canada/services/health-concerns/reportspublications/emergencies-disasters/federal-nuclear-emergency-plan-part-1-master-plan.html>.

85 Public Safety Canada, Federal Emergency Response Plan (Ottawa: PSC, 2011), online: $<$ https://www. publicsafety.gc.ca/cnt/rsrcs/pblctns/mrgnc-rspns-pln/mrgnc-rspns-pln-eng.pdf $>$ [FERP].

Ibid at 2.

EMP Guide, supra note 8 at 3; EMA (Canada), supra note 79, s 6(2).

EMP Guide, ibid (for example, by identifying alternate facilities such an emergency hospital).

Public Safety Canada's website does not include government operational plans or business continuity plans: see "Emergency Management Planning" (Otttawa: PSC, 2016), online: <https://www.public safety.gc.ca/cnt/mrgnc-mngmnt/mrgnc-prprdnss/mrgnc-mngmnt-plnnng-en.aspx $>$. Environment and Climate Change Canada has only high-level descriptions of its emergency management practices: see "Environmental Emergencies: National Environmental Emergencies Centre" (Ottawa: Government of Canada, 2017), online: <https://www.canada.ca/en/environment-climate-change/services/environmentalemergencies-program/national-centre.html $>$. Emergency management plans are not listed or provided on the Natural Resources Canada website, although a 2014 publicly-available audit identifies that Natural Resources Canada has developed and maintained to a reasonable standard nine of these plans: Natural Resources Canada, Audit of NRCan's Management Framework for Responsibilities Under the Emergency Management Act (EMA) (AU1502) (Ottawa: NRC, 2014), online: <www.nrcan.gc.ca/audit/ reports/2014/17039>. 
Finally, in accordance with the legislated responsibilities, the federal government maintains a Government Operations Centre (GOC), which is responsible for " $24 / 7$ monitoring and reporting, national-level situational awareness, warning products and integrated risk assessments, as well as national-level planning and whole-of-government response management." $" 90$ The GOC carries out the actual work of emergency preparedness by continually assessing and updating emergency management plans in coordination with the provinces and territories, conducting training exercises, and providing support to senior public officials and keeping them apprised of potential threats. ${ }^{91}$ The GOC was activated during the Fort McMurray wildfire to ensure "federal efforts were coordinated to support the Province of Alberta." 92

This basic four-part structure is replicated at the provincial level. The Alberta Emergency Management Act legislates multiple stages of the disaster cycle. ${ }^{93}$ It constitutes an Emergency Management Agency, ${ }^{94}$ which takes the lead in disaster preparedness. Pursuant to regulations under the EMA (Alta), the Agency "shall ... develop, implement and maintain a comprehensive plan to be known as the "Alberta Emergency Plan." 95 And the province institutionalizes these preparedness requirements through a government operations centre.

The Alberta Emergency Plan has several mandatory components, including additional plans developed in coordination with relevant government departments. While the Alberta Emergency Plan is not publicly available, ${ }^{96}$ several of the more specific plans are. Business continuity plans serve the same purpose as their federal counterparts; that is, to ensure continuity in the delivery of essential government services during a period of disruption. ${ }^{97}$ Hazard-specific management plans set out actions for all stages of the disaster cycle with respect to specific kinds of disasters. ${ }^{98}$ For example, the Alberta Wildland / Urban Interface Fires plan states that it provides "a comprehensive ... [s]trategy designed to prevent and mitigate the effects of an interface fire, prepare for fire events, respond effectively ... and efficiently recover from the effects of wildfires." ${ }^{99}$ In terms of preparedness, the plan sets out even further planning requirements, namely a detailed emergency plan that includes, amongst other requirements, key contact information, standing firefighting resource inventory, a list of prioritized critical infrastructure, and significant dangerous goods sites. The Interface

Public Safety Canada, "Government Operations Centre (GOC)" (Ottawa: PSC, 2016), online: <https:// www.publicsafety.gc.ca/cnt/mrgnc-mngmnt/rspndng-mrgnc-vnts/gvrnmnt-prtns-cntr-en.aspx>.

Ibid.

92 Defence Research and Development Canada, News Release, "Supporting Emergency Management Officials During the Fort McMurray Wildfire Response" (2 May 2017), online: <www.drdcrddc.gc.ca/en/dynamic-article.page?doc=supporting-emergency-management-officials-during-the-fortmcmurray-wildfire-response/j1wgdft5 $>$.

RSA 2000, c E-6.8 [EMA (Alta)].

Ibid, s 3.1.

Government Emergency Management Regulation, Alta Reg 248/2007, s 2(1)(c) [GEMR].

The lack of public accessibility of this central aspect of emergency preparedness is of concern. One can imagine reasons why some portions of the plan ought to be confidential - to protect personal contact information or for security reasons - but public scrutiny is a vital means of ensuring adequacy of preparedness.

97 GEMR, supra note 95, s 1(c). See Alberta Emergency Management Agency, Government of Alberta Business Continuity Plan (Edmonton: AEMA, 2013), online: $<$ www.aema.alberta.ca/documents/GOA BCP 2014.pdf>.

GEMR, ibid, ss i(d), 2(1)(e).

99 Alberta Emergency Management Agency, Alberta Wildland / Urban Interface Fires: A Guide for Municipal Directors of Emergency Management and Consequence Management Officers (Edmonton: AEMA, 2015) at 5, online: <www.aema.alberta.ca/documents/Alberta-Wildland-Urban-InterfaceFires.pdf $>$ [emphasis in original] [AEMA, Interface Fires]. 
Fires plan requires that this detailed emergency plan be rehearsed through exercises and training of emergency responders.

A comprehensive post-fire assessment of the government response, commissioned by the provincial government, identified the absence of several crucial preparedness plans that affected Alberta's response to and recovery from the wildfire. For example, the report noted the lack of a provincial Emergency Evacuation Framework that would take advantage of known modeling and simulation tools to identify appropriate evacuation routes. ${ }^{100}$ The report also identified the absence of clear processes in the Alberta Emergency Plan for who is delegated authority under the plan and how that authority must be exercised. ${ }^{101}$ The absence of these key plans emphasizes the need for greater transparency in emergency preparedness. At present, it is not clear to the public whether important plans (for example, an evacuation plan) exist but are not publicly-accessible, or do not exist at all.

Like its federal counterpart, the province also maintains a round-the-clock Provincial Operations Centre, which was fully activated during the Fort McMurray wildfire. ${ }^{102}$ After the wildfire, the provincial government announced the investment of $\$ 125$ million for modernizing the Provincial Operations Centre to become a leader in emergency response. ${ }^{103}$

Again, these four features are present at the municipal level. The EMA (Alta) requires local authorities to maintain an "emergency management agency," which is also required to prepare and coordinate local emergency plans and programs. ${ }^{104}$ The Regional Municipal Authority of Wood Buffalo has complied with this legislated requirement, establishing an emergency management agency that consists of the Mayor and Councillors of the municipality. ${ }^{105}$ Like its provincial and federal counterparts, this local agency is required, in accordance with the bylaw and provincial legislation, to "prepare and coordinate emergency plans and programs" for the region. ${ }^{106}$ Wood Buffalo maintains a general Municipal Emergency Management Plan that allows for a flexible response to any type of emergency. ${ }^{107}$ Finally, Wood Buffalo's Regional Emergency Operations Centre was activated during the Fort McMurray wildfire. ${ }^{108}$

The lack of transparency of many of the crucial plans makes it difficult to definitively assess both the approach and adequacy of the contents of these plans. The lack of public

KPMG LLP, supra note 22 at 66.

Ibid at 58 .

Alberta Emergency Management Agency, "Provincial Operations Centre (POC)" (Edmonton: AEMA, 2017), online: <www.aema.alberta.ca/provinicial-operations-centre>; Government of Alberta, Home Again, supra note 17 at 7.

Alberta, Treasury Board and Finance, Budget 2017: Working to Make Life Better: Fiscal Plan (Edmonton: Treasury Board and Finance, 2017) at 42-43, online: $<$ www.finance.alberta.ca/publications/ budget/budget2017/fiscal-plan-complete.pdf $>$.

Supra note 93, s 11.2.

Regional Municipality of Wood Buffalo, by-law No 09/036, Emergency Management Agency Bylaw (17 November 2009).

Ibid, s 12(a).

Regional Municipality of Wood Buffalo, "Emergency Management Branch,” online: <www.rmwb.ca/ Municipal-Government/municipal_departments/Emergency-Services---Law-Enforcement/EmergencyManagement.htm>.

Regional Municipality of Wood Buffalo, RMWB 2016 Wildfire Recovery Plan (Fort McMurray: RMWB, 2016) at 9 [RMWB, Recovery Plan]. 
accessibility raises questions about the efficacy of these plans in addition to deeper questions about their legal and democratic authority. ${ }^{109}$

\section{The Absence of a Vulnerability Perspective}

The legal requirements of preparedness do not incorporate the multi-dimensional concept of vulnerability, introduced in Part II. In contrast to the context-sensitive notion of vulnerability, which attends to the particular intersections between social and ecological relationships, the law of disaster preparedness is technical and uniform in nature.

First, the legal division between "disaster" and "emergency," noted above, foreshadows the problem. Canadian governments do not engage in disaster management, which foregrounds harm and vulnerability as the central features of a disaster. Rather, Canadian governments engage in emergency management, which focuses on the institutional practices of managing emergencies (or disasters, on this article's definition). This risks emergency management becoming a set of technical practices of institutional coordination, disconnected from their ultimate purpose.

For example, Canada's EMP Guide, the key document instructing departments on all stages of the disaster cycle, requires public officials to conduct vulnerability assessments. However, "vulnerability" is used as a technical term that does not capture the multidimensionality of the concept explored in Part II. The EMP Guide describes vulnerability as "an inadequacy or gap in the design, implementation or operation of an asset that could enable a threat or hazard to cause injury or disruption." "110 Vulnerability, in this context, seems to apply to the emergency management process itself. ${ }^{111}$ This is an important facet of disaster management to be sure. We want our institutions to engage in these management practices to ensure they have the training, resources, and organization to respond to all hazards our communities may face. However, that this is the only reference to vulnerability in the law of disaster preparedness is striking in light of the concept's multi-faceted analytical and practical potential.

Second, the EMP Guide focuses on hazards, assets, and services but does not address the underlying factors that contribute to social vulnerability. Despite this basic insight on vulnerability from disaster research and international practice, there is no federal policy framework developed under the EMA (Canada) that identifies which individuals or communities are most vulnerable to disasters. Nor is there any formal guidance to decisionmakers that they ought to take steps to identify these groups when developing an emergency plan.

Jocelyn Stacey, "The Environmental, Democratic, and Rule-of-Law Implications of Harper's Environmental Assessment Legacy" (2016) 21:2 Rev Const Stud 165 (on how changes to federal environmental assessment laws undermined the democratic and legal legitimacy of Canadian environmental law).

110 Supra note 8 at 16.

111 The EMP Guide offers the following as examples of vulnerabilities: "personnel issues (e.g. high turnover, inadequately trained individuals)"; "insufficient secondary or support processes"; and "existing [Emergency Management] plans that are immature and have not been tested" (ibid). 
To take one example, if we focus in on one known vulnerable group, Indigenous Canadians, it becomes even more apparent that Canadian disaster law fails to adopt a vulnerability perspective. Canada's Auditor General reported on emergency management on reserve land, highlighting the special vulnerability faced by First Nations communities due to "poor socio-economic conditions, low education levels, and few economic opportunities" in addition to "isolation and geographic location." 112 The Auditor General noted chronic and repeated exposure to hazards such as flooding, wildfire, and unsafe drinking water. ${ }^{113}$

The federal approach to disaster management on reserves is contained in the National Onreserve Emergency Management Plan. The plan states that " $[\mathrm{t}]$ he responsibility to deal with emergency incidents starts at home with the individual" and recommends that individuals have a 72-hour emergency preparedness kit. ${ }^{114}$ As the starting point of the plan, this recommendation fails to reflect the level of poverty experienced on many reserves that prevents many from making ends meet during ordinary times, not to mention times of crisis. ${ }^{115}$ The National On-reserve Management Plan further affirms that emergency management is the responsibility of the local community. Yet there is no guaranteed funding or resources to enable First Nations communities to adequately conduct emergency management activities. ${ }^{116}$ Unsurprisingly — but of tremendous concern — the Auditor General found that less than half of the studied First Nations' emergency plans had assessed the hazards and risks faced by the community, leaving these communities unnecessarily vulnerable to disaster harm. ${ }^{117}$

This lack of attention to vulnerable communities in Canadian disaster law reveals the importance of analyzing disasters in all their socio-ecological dimensions, rather than relying exclusively on an all-hazards analysis of emergencies. This is because very different communities are typically vulnerable to environmental hazards, rather than emergencies arising from national security concerns. Terrorist actions are intentionally high-visibility events that do not obviously discriminate based on race or socio-economic status. ${ }^{118}$ Research on disaster vulnerability reveals that disasters are not the social equalizers they were once thought to be. ${ }^{119}$ Rather, empirical evidence demonstrates that disaster harm is disproportionately suffered by communities that are already marginalized, such as Canada's Indigenous communities.

Office of the Auditor General of Canada, 2013 Fall Report of the Auditor General of Canada (Ottawa: Auditor General of Canada, 2013) ch 6, online: <www.oag-bvg.gc.ca/internet/English/parl_oag 201311 06 e 38800.html $>$ [2013 Fall Report].

113 Ibid, $6 . \overline{16}-\overline{6} . \overline{18}$.

114 Indigenous and Northern Affairs Canada, National On-reserve Emergency Management Plan (Ottawa: INAC) at 6-7, online: $<$ https://www.aadnc-aandc.gc.ca/DAM/DAM-INTER-HQ-AP/STAGING/textetext/emergency plan 1496943857348 eng.pdf $>$.

115 See generally Indigeñous and Northern Affairs Canada, "The Community Well-Being (CWB) Index, 1981-2011" (Ottawa: INAC, 2015), online: <https://www.aadnc-aandc.gc.ca/eng/1419864229405/ $1419864303946>$.

116 Indigenous Services Canada now runs an Emergency Management Assistance Program, to which interested First Nations communities must apply to receive project specific funding: Indigenous Services Canada, "Emergency Management Assistance Program: Funded Projects 2016-2017" (Gatineau: ISC, 2017), online: <https://www.aadnc-aandc.gc.ca/eng/1488801706500/1488801742929>. 2013 Fall Report, supra note 112 at para 6.30 anywhere. To the extent that wealthier individuals participate in activities that might attract terrorist plots (for example, travelling by air or attending a concert), they would be more exposed to these hazards than those who do not participate in these activities (whether by choice or ability). Verchick, Facing Catastrophe, supra note 40 at 190. 
Indeed, multiple First Nations and Métis communities were affected by the Fort McMurray wildfire, in addition to the hardest-hit neighbourhoods in Fort McMurray being home to the majority of Fort McMurray's Indigenous population. ${ }^{120}$ Yet the effects of the disaster on these communities is largely absent from official responses. ${ }^{121}$ Moreover, neither the provincial or federal government has used the Fort McMurray wildfire as an opportunity to extrapolate any broader lessons for First Nations emergency management, despite the fact that First Nations are the largest population affected by wildfire evacuation in Canada. ${ }^{122}$

A necessary first step for Canadian disaster law to begin to incorporate a vulnerability perspective is for disaster preparedness to refocus on vulnerable communities. Legal requirements and policy guidelines must direct emergency managers to identify vulnerable communities and populations when crafting mandatory emergency plans. These requirements must manifest at each level of government. While local governments are best positioned to understand their own communities and the marginalized and vulnerable populations within them, leadership and support must come from provincial and federal governments. Provincial emergency legislation ought to mandate that emergency plans identify and attend to vulnerable communities. Federal leadership, at the very least, could come in the form of dictating a methodology for officials who are required to carry out these tasks. Failing to incorporate these requirements into the law of disaster planning exacerbates community vulnerability.

\section{B. The LAW OF Disaster Response}

The law of disaster response has two key features mirrored at each level of government: (1) the legislated ability to declare a state of emergency; and (2) special delegated powers to respond to the emergency. These features operationalize the "toggle switch" approach to disasters, introduced above, meaning that these special sets of powers govern during a state of emergency, in contrast to the operation of ordinary legislative requirements that apply at all other times.

Disaster response is addressed in the first and second instances by the local and provincial governments. Provincial legislation, for example, the EMA (Alta), is therefore the focal point of the emergency response. The EMA (Alta) draws the same distinction between "disaster" and "emergency" "123 as the inter-governmental framework introduced above, with "disaster" focusing on the harm and the "emergency" focusing on the immediate cause of the disaster and the institutional response.

Shari Narine, "Impact of Wildfire on Indigenous Residents to be Studied," Windspeaker (28 March 2017), online: <www.windspeaker.com/news/windspeaker-news/impact-of-wildfire-on-indigenousresidents-to-be-studied/>.

${ }_{121}$ Government of Alberta, Home Again, supra note 17 at 10, 26 (provincial support for restoring lost traplines); KPMG LLP, supra note 22 at 36, 77 (on special communications challenges with Indigenous communities). The Red Cross, however, has committed to funding a study on the impacts of the Fort McMurray wildfire on Indigenous people: David Thurton, "Impact of Wildfire on Fort McMurray Indigenous Communities to be Studied," CBC News (9 November 2016), online: $<$ www.cbc.ca/news/canada/edmonton/impact-of-wildfire-on-fort-mcmurray-indigenous-communities-tobe-studied-1.3842391>. Renewed Call to Action (Ottawa: Natural Resources Canada, 2016) at 9, online: $<$ www.cfs.nrcan.gc.ca/ pubwarehouse/pdfs/37108.pdf $>$. 
The EMA (Alta) delegates power to the municipalities to declare states of local emergency ${ }^{124}$ and to the Lieutenant Governor in Council to declare a provincial state of emergency. ${ }^{125}$ The EMA (Alta) does not set out conditions required to constitute an emergency. Rather, it requires only that the local government or Lieutenant Governor in Council "is satisfied" that an emergency exists. ${ }^{126}$ The declaration must disclose the nature of the emergency and the area of the province to which it applies. ${ }^{127}$ Due to the urgency of the circumstances, the EMA (Alta) requires the declaration to be published immediately in whatever manner is likely to reach the majority of the affected population. ${ }^{128}$

These states of emergency can be terminated at any time by the delegated authority. ${ }^{129}$ Local and provincial states of emergency have legislated sunset periods, meaning that in the absence of an affirmative renewal, the declaration automatically lapses. ${ }^{130}$ A provincial state of emergency pertaining to the same area immediately supersedes the state of local emergency and causes it to be of no force or effect. ${ }^{131}$

The Regional Municipality of Wood Buffalo has elaborated these powers through its municipal bylaws. Under the relevant bylaw, the Mayor has the power to declare a state of local emergency. ${ }^{132}$ The Mayor declared a state of local emergency for Fort McMurray at 10:00 p.m. on 1 May 2016. A state of local emergency followed for Athabasca Chipewyan First Nation on 3 May 2016. Notices were published through Alberta Emergency Alert notifications and circulated through government news releases and social media, but the postfire audit identified the need for an improved coordinated communications strategy. ${ }^{133} \mathrm{On}$ 4 May 2016, the provincial government declared a state of provincial emergency through a brief Order in Council, stating:

WHEREAS the Lieutenant Governor in Council is satisfied that an emergency exists in the Regional Municipality of Wood Buffalo as a result of wildfires, which have caused extraordinary losses and damages to residents, businesses and others.

THEREFORE the Lieutenant Governor in Council declares that a state of emergency exists in the Regional Municipality of Wood Buffalo. ${ }^{134}$

The EMA (Alta) delegates special emergency powers to local authorities operating under a state of local emergency as well as to the Minister during a state of provincial emergency. These powers include implementing the emergency plan, acquiring real or personal property needed to respond to the emergency, controlling or prohibiting travel to regions of the

Ibid, s 21(1).

Ibid, s 18(1).

Ibid, ss 18(1), 21(1).

Ibid, ss 18(2), 21(2).

Ibid, ss 18(3), 21(3).

Ibid, ss 18(4), 22(4).

Ibid.

Ibid, s 22 (3).

Emergency Management Agency Bylaw, supra note 105, s 14.

KPMG LLP, supra note 22 at 79-82.

OIC 107/2016, supra note 29. 
province, and ordering evacuations. ${ }^{135}$ The latter power was exercised repeatedly during the Fort McMurray wildfire, with the municipal government issuing ever-expanding mandatory evacuation orders on 3 May 2016 and subsequent evacuation orders issued by the province as the fire spread north of the city. ${ }^{136}$ However, the post-fire assessment noted inconsistency in the implementation of the emergency response between the local and provincial levels. The assessment recommended changing the legislation to require a uniform incident response system across all local authorities. ${ }^{137}$

At the federal level, the Emergencies $A c t^{138}$ contains the same toggle switch approach that enables the declaration of a federal state of emergency and special response actions. For reasons we will see in a moment, the federal government did not declare a state of emergency during the Fort McMurray wildfire; however, it did respond in other ways.

Canada's EA is the more circumscribed successor to the War Measures Act, which delegated sweeping authority to the executive upon the declaration of a state of emergency. ${ }^{139}$ Unlike the provincial legislation, the federal EA specifies four distinct categories of emergencies: public welfare emergency, public order emergency, international emergency, and war emergency. ${ }^{140}$ Each category has different prerequisites to the declaration of a state of emergency and different emergency response powers that are delegated to the executive during a state of emergency. Significantly, in each instance, the event must be a "national emergency" or what the legislation defines as:

[A]n urgent and critical situation of a temporary nature that

(a) seriously endangers the lives, health or safety of Canadians and is of such proportions or nature as to exceed the capacity or authority of a province to deal with it, or

(b) seriously threatens the ability of the Government of Canada to preserve the sovereignty, security and territorial integrity of Canada

and that cannot be effectively dealt with under any other law of Canada. ${ }^{141}$

Disasters such as wildfires, floods, storms, epidemics, and accidents or pollution are categorized as public welfare emergencies by the legislation. ${ }^{142}$ The Governor in Council may declare a state of emergency in response to one of these events "that results or may result in a danger to life or property, social disruption or a breakdown in the flow of essential goods, services or resources, so serious as to be a national emergency." ${ }^{\text {"143 }}$ During a state of public welfare emergency, the Governor in Council is empowered to make numerous kinds of orders which it "believes, on reasonable grounds, are necessary," including orders

EMA (Alta), supra note 93, s 19(1).

See "Wildfire," supra note 23. Note that there is no legislative authority to compel someone to comply with a mandatory evacuation order. The post-fire assessment recommended considering an amendment to the legislation to create an offence for non-compliance: KPMG LLP, supra note 22 at 66-67. KPMG LLP, ibid at 85 .

RSC 1985, c 22 (4th Supp) [EA].

See e.g. Peter Rosenthal, "The New Emergencies Act: Four Times the War Measures Act” (1991) 20:3 Man LJ 563.

Supra note 138 , ss 5, 16, 27, 37.

Ibid, s 3 .

Ibid, s 5.

Ibid, ss 5-6. 
pertaining to the regulation or prohibition of travel to certain areas, evacuations, requisition or use of property, establishment of emergency shelters, as well as the imposition of fines and terms of imprisonment for violating these orders. ${ }^{144}$

The EA has never been invoked. This is likely due to the high threshold posed by the definition of "national emergency." The typically geographically-defined nature of most disasters means they are unlikely to meet the requirements of a national emergency. ${ }^{145}$

Under the EMA (Canada) and National Defence Act, however, the federal government is empowered to play a supportive role in provincial disaster response efforts. ${ }^{146}$ Both Acts empower the federal government to provide assistance to the provinces during provincial emergencies. Under the EMA (Canada), the federal Minister of Public Safety and Preparedness can provide financial assistance for disaster response upon declaring a provincial emergency a matter of "concern to the federal government." the provincial government requested financial assistance for the response to the Beast. The federal government responded by declaring the provincial emergency "to be of concern to the federal government" and authorizing the Minister to provide financial assistance. ${ }^{148}$

In addition, provincial attorneys general are able to call upon the Canadian Armed Forces "in aid of the civil power in any case in which a riot or disturbance of the peace" exceeds the powers of civil authorities. ${ }^{149}$ National Defence and the Canadian Armed Forces has established "Operation LENTUS," a standing operation that provides humanitarian assistance and disaster response support when a disaster overwhelms the capacity of the province or territory. ${ }^{150}$ On 4 May 2016, the province requested assistance from the armed forces. Operation LENTUS deployed 65 personnel, five helicopters, and an aircraft to assist with transporting evacuees, firefighters, and freight during the peak period of emergency response. $^{151}$

The role of law in delineating the conditions for the toggle switch to emergency powers is well-established. ${ }^{152}$ Accordingly, the legal requirements for emergency powers and mechanisms for intergovernmental coordination are clearly delineated in both federal and provincial legislation.

The challenge that arises at the response stage is that of realizing the coordination amongst jurisdictions that is anticipated by statute. The implementation of these emergency powers in response to the Beast highlighted the need to improve capacity at the local level to ensure

Ibid, ss 8(1)(a)-(j).

However, one can imagine a scenario in which an extreme event struck a provincial capital city, incapacitating the provincial government and requiring the federal government to step in to assume responsibility for the response.

National Defence Act, RSC 1985, c N-5 [NDA]. The federal government also has specific disaster response obligations with respect to its areas of exclusive jurisdiction: see e.g. Railway Safety Act, RSC 1985, c 32 (4th Supp); Nuclear Safety and Control Act, SC 1997, c 9.

Supra note 79 , ss 4(1)(j), 7(c).

Provincial Emergency Financial Assistance Order No 197, PC 2016-0525 (14 June 2016).

NDA, supra note 146, s 275.

National Defence and Canadian Armed Forces, "Operation LENTUS," online: <www.forces.gc.ca/en/ operations-canada-north-america/op-lentus.page>.

Ibid.

See e.g. Clinton Rossiter, Constitutional Dictatorship: Crisis Government in the Modern Democracies (Princeton: Princeton University Press, 1948); Gross \& Aoláin, supra note 67, ch 1. 
a consistent approach between local and provincial authorities. While coordination may perhaps appear an excessively bureaucratic detail, it is crucial to ensuring that vulnerable communities do not fall through the cracks in disaster response.

\section{The LAW OF Disaster RECOVERY}

The law of disaster recovery focuses principally on compensation for harm suffered during disasters. ${ }^{153}$ This section provides a more comprehensive map of the law of disaster recovery. After first discussing the compensatory aspects of the law of recovery, it identifies the "ordinary" non-emergency laws that have particular salience during the recovery stage. It argues that these planning and development laws are essential to fulfilling the recovery objective of building back better (that is, the goal of rebuilding communities so they are more resilient to future hazards).

\section{COMPENSATION}

The compensatory aspect of recovery itself has three components: (1) private insurance; (2) tort law; and (3) legislated compensation and disaster relief programs. The first two components will be addressed relatively briefly as they are their own distinct areas of law and cannot be addressed in great depth within the scope of this article.

Disaster compensation raises basic questions about who ought to bear the risk of disaster loss: individuals or the state. The availability of private insurance shifts that obligation to individuals. Fire is typically an insurable event. ${ }^{154}$ In the instance of the Fort McMurray wildfire, insurance companies report that they anticipate spending $\$ 3.6$ billion for the recovery from the 2016 Fort McMurray wildfire. ${ }^{155}$ Whether any significant legal issues arise from the adjudication of claims from this wildfire remains to be seen.

Disasters pose challenges for private insurers due to their unpredictable, significant, and concentrated losses that make it difficult for insurers to spread risk. As a result, private insurance plans often exclude coverage for disasters. For example, until recently, private insurance has not covered flood loss in Canada. ${ }^{156}$ Current flood insurance coverage is expensive because only those at risk are likely to purchase coverage. ${ }^{157}$ This evidences a central challenge inherent to the logic of insurance: setting the right price to incentivize individuals to purchase insurance while still ensuring companies can pay out claims when a major event occurs. Climate change exacerbates these challenges by increasing uncertainties for insurance companies, exacerbating multiple correlated risks (for example,

AEMA, Interface Fires, supra note 99 at 14-15. The Public Safety Canada webpage on recovery is exclusively focused on compensation: "Recovery from Disasters" (Ottawa: PSC, 2017), online: $<$ https://www. publicsafety.gc.ca/cnt/mrgnc-mngmnt/rcvr-dsstrs/index-en.aspx $>$. See also Farber, supra note 41 at 1787 .

The Insurance Bureau of Canada outlines disaster coverage that is typically covered in standard home insurance policies: "Disaster," online: $<$ www.ibc.ca/bc/disaster $>$ (noting that overland flood insurance and earthquake coverage are not included in standard policies). Government of Alberta, Home Again, supra note 17 at 25. Jason Thistlethwaite, "The Emergence of Flood Insurance in Canada: Navigating Institutional Uncertainty" (2017) 37:4 Risk Analysis 744.

157 Office of the Parliamentary Budget Officer, Estimate of the Average Annual Cost for Disaster Financial Assistance Arrangements due to Weather Events (Ottawa: PBO, 2016) at 11, online: <www.pbodpb.gc.ca/web/default/files/Documents/Reports/2016/DFAA/DFAA_EN.pdf>. 
wildfire and flooding), and threatening insurers with the possibility of claims that are overwhelming in terms of both amount and number. ${ }^{158}$ Climate-related disasters thus force us to revisit basic questions of both policy and institutional design for insuring against expected, but ultimately unpredictable and likely extreme losses.

Individuals who suffer harm or loss can attempt to obtain compensation from those responsible. Ordinarily, principles of tort liability mediate this relationship. In the limited existing disaster law literature, one scholar has argued our increasingly sophisticated sociological understanding of disasters allows for an increased scope for liability. ${ }^{159} \mathrm{He}$ observes that, in prominent instances worldwide, defendants in tort actions have been less able to rely on unforeseeability defences, such as the act of God defence. As disasters are increasingly understood as expected, if not entirely predictable occurrences, courts have begun to require that public and private actors account for the possibility of disaster when taking actions that affect others. ${ }^{160}$

While these defences may be verging on extinction, the ability to successfully claim damages in tort for disaster harm remains significantly restricted. Litigation after Hurricane Katrina demonstrated the difficulty of proving the negligence of public authorities in disaster prevention because disaster prevention decisions are typically considered policy decisions that are not the subject of liability. ${ }^{161}$ Similarly, in Canada, potential plaintiffs would face the doctrinal challenge of establishing their proximity to the public authority ${ }^{162}$ and navigating the policy-operational dichotomy which generally protects governments from liability for policy decisions. ${ }^{163}$

These doctrinal hurdles would also apply to the disaster response actions taken by public authorities. In addition, emergency response actions are covered by statutory immunity clauses that protect public authorities from liability for actions taken in good faith. The federal $E A^{164}$ and the provincial EMA (Alta) ${ }^{165}$ contain immunity clauses that protect ministers, agents of the Crown, and local authorities against liability for any action or omission made in good faith pursuant to the emergency legislation. The provincial legislation contains further immunity against actions in negligence for actions taken in good faith by search and rescue organizations while acting under an agreement with the Minister. ${ }^{166}$

See Sean B Hecht, "Climate Change and the Transformation of Risk: Insurance Matters" (2008) 55:6 UCLA L Rev 1559.

Lauta, supra note 35 at 105.

For example, the corporate defendant at fault in the Fukushima disaster did not mount a defence based on the statutory immunity clause for natural disasters of "exceptional character" because of the accepted view that the tsunami was an anticipated occurrence and not of "exceptional character" (ibid at 123). Ibid (noting changes in the doctrine with a later-reversed lower court finding that failing to maintain the levees "was not policy, but insouciance, myopia and shortsightedness" at 29, citing In re Katrina Canal Breaches Consolidated Litigation, 647 F Supp (2d) 644 (ED La 2009) at 732).

See e.g. Eliopoulos (Litigation Trustee of) v Ontario (Minister of Health and Long-Term Care) (2006), 82 OR (3d) 321 (CA), leave to appeal to SCC refused, 31783 (24 May 2007) (no duty of care to prevent the spread of the West Nile virus).

See e.g. $R v$ Imperial Tobacco Ltd, 2011 SCC 42, [2001] 3 SCR 45. For a general discussion of this notoriously tricky doctrine, see Lewis N Klar \& Cameron SG Jefferies, Tort Law, 6th ed (Toronto: Thomson Reuters, 2017) at 364-74.

Supra note 138, s 47(1).

Supra note 93, ss 27-28.

Ibid, s 29. 
Some of these aspects of tort doctrine and statutory protections have legitimate policy rationales. They serve to limit judicial overreach into thorny policy issues pertaining to disaster prevention, and recognize that emergency response actions are taken in the heat of the moment, often with limited information. But international experience with disaster prevention and response highlights a striking number of instances in which incompetent, indifferent, and profligate actions by public officials, in particular, have significantly contributed to disaster harm. ${ }^{167}$ This suggests that tort law could play a much more extensive role in compensating those who have suffered disaster harm. Moreover, experience in the United States suggests that a plausible claim in tort is an important factor in prompting the government to establish adequate compensation funds, ${ }^{168}$ to which this section now turns.

Legislated compensation and disaster relief programs are more complex in structure. Most directly, both provincial and federal legislation provide that, if the government acquires, utilizes, damages, or destroys any personal or real property during its emergency response, it shall provide reasonable compensation for the loss. ${ }^{169}$

Above and beyond this form of compensation, both the province and federal governments have detailed programs for providing broader financial disaster relief for uninsured losses. The EMA (Alta) constitutes a Disaster Relief Fund, which is administered by a Disaster Relief Committee. ${ }^{170}$ The Disaster Recovery Regulation sets out how the funds are to be

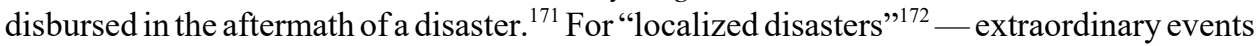
that affect a small number of people - those individuals apply to a Director for compensation for eligible losses. ${ }^{173}$ For widespread disasters, such as the Fort McMurray wildfire, the Minister establishes a disaster recovery program with specific terms and conditions for compensation, forms in which the compensation will be provided, and any special provisions for assessment of damage and loss. ${ }^{174}$

Disaster recovery programs are administered through the Alberta Emergency Management Agency. Affected municipalities apply on behalf of their residents. ${ }^{175}$ Fort McMurray initially received $\$ 87.5$ million in disaster recovery program funding to help the city pay for the

Hurricane Katrina stands out here: see Klar \& Jefferies, supra note 163. See also Penny Green, "Disaster by Design: Corruption, Construction and Catastrophe" (2005) 45:4 Brit J Crim 528 (examining a series of earthquakes in Turkey and arguing that state power, corruption, and corporate power "combine as state crime to create earthquake disasters" at 528). See discussion in Verchick, Facing Catastrophe, supra note 40 at 179-80. EMA(Alta), supra note 93, ss 19(3), 24(1.1); Byron Hills Resources Ltd v Alberta (Sustainable Resource Development), 2009 ABQB 292, 473 AR 71 (on the applicability of the compensatory provisions of predecessor legislation to EMA (Alta)); EA, supra note 138, s 48(1).

EMA (Alta), ibid, s 12.

Disaster Recovery Regulation, Alta Reg 51/1994.

Ibid, s 1(d).

Ibid, ss 3, 9 (on eligible losses), s 5 (application procedure), ss 7-8 (appeal procedures).

Ibid, s 4 . Note that the province also has Municipal Wildfire Assistance Programs that provide financial assistance to municipalities for the costs directly associated with the suppression of wildfire, salaries of firefighting personnel, fireguard construction, and so on: Alberta Emergency Management Agency, "Municipal Wildfire Assistance Programs (MWAPs)"(Edmonton: AEMA, 2016), online: <www.aema. alberta.ca/municipal-wildfire-assistance-programs $>$.

175 Alberta Emergency Management Agency, "Assistance and Recovery Support" (Edmonton: AEMA, 2017), online: <www.aema.alberta.ca/assistance-and-recovery-support>. 
response and recovery from the fire. ${ }^{176}$ In February 2017, the province announced an additional \$20 million would be disbursed through the program. ${ }^{177}$

Canada also administered disaster relief funding though the federal Disaster Financial Assistance Arrangements (DFAA). ${ }^{178}$ The DFAA provides assistance to provincial and territorial governments when response and recovery costs exceed their capability. The DFAA has detailed guidelines for cost sharing arrangements between the affected province or territory and the federal government. ${ }^{179}$ The province or territory must apply for the funding; however, the DFAA will not cover expenses where "insurance coverage for a specific hazard ... was available in the area at reasonable cost." 180

The federal government provided its first installment of DFAA funding, \$300 million, to Alberta in June 2016. ${ }^{181}$ The Alberta government has reported on the use of the funding (above and beyond covering the costs of the wildfire response). It announced that over $\$ 18$ million would be spent on mental health initiatives in the recovery period, $\$ 4.8$ million in financial assistance would be allocated to evacuees to cover gaps in insurance, and an additional $\$ 1.7$ million would be disbursed to provide income support for low-income households. ${ }^{182}$ While these initiatives are laudable, it is worth noting that there is nothing in Alberta's Disaster Recovery Regulation that requires funds be allocated toward vulnerable groups. As vulnerable groups are, by definition, in the most precarious positions both before and after disasters, access to these funds are especially important in ameliorating their continued vulnerability. ${ }^{183}$ This specific focus on recovery re-emphasizes the significance of the absence of any requirements at the planning stage that mandate and guide the identification of vulnerable communities in advance of a disaster.

\section{PlaNNING \& DEVELOPMENT}

While compensation is often the focal point of disaster recovery, this section argues that disaster law properly includes the suite of planning and development laws that take on a heightened importance during disaster recovery. This section reveals, however, that existing disaster law lacks formal connections between emergency laws and the planning and development laws that are essential to communities building back better. In the aftermath of the Beast, most significant recovery actions were taken in the absence of any specific legal mandate to do so.

Government of Alberta, Home Again, supra note 17 at 32.

"Government of Alberta Advances Disaster Recovery Program Funding to Help with Fort McMurray Uninsurable Costs," Canadian Underwriter (24 February 2017), online: <https://www.canadian underwriter.ca/insurance/government-alberta-advances-disaster-recovery-program-funding-help-fortmcmurray-uninsurable-costs-1004109363/>.

Pursuant to EMA (Canada), supra note 79, s 4(1)(j).

Public Safety Canada, Guidelines for the Disaster Financial Assistance Arrangements (Ottawa: PSC, 2007), online: $<$ https://www.publicsafety.gc.ca/cnt/mrgnc-mngmnt/rcvr-dsstrs/gdlns-dsstr-ssstnc/gdlnsdsstr-ssstnc-eng.pdf $>$ [DFAA Guidelines].

Ibid, s 3.1.2(b). A number of other losses are ineligible as well, including lost income, losses due to ordinary or normal risks of a trade, and legal fees (ibid).

Alberta Municipal Affairs, News Release, "Governments of Canada and Alberta Announce Continued Support for People of Fort McMurray" (17 June 2016), online: $<$ https:/www.alberta.ca/release.cfm?x ID=42944BBDA58F8-00F1-62F5-5D713EC19F3EFE86>.

Government of Alberta, Home Again, supra note 17 at 28, 30.

Verchick, Facing Catastrophe, supra note 40 at 178. 
In most instances - as with the Fort McMurray wildfire - the applicable planning and development law is at the provincial and local levels. Recovery from the Fort McMurray wildfire was overseen by provincial and local Recovery Committees. The Alberta Recovery Task Force was created through Order in Council, with a mandate to work with the municipality and Indigenous communities to develop a recovery plan. ${ }^{184}$ The Wood Buffalo Recovery Committee was constituted through bylaw with a mandate of working closely with a Recovery Task Team that would implement recovery actions. ${ }^{185}$ The product of these committees is the Wood Buffalo Recovery Plan, which "is intended to guide the recovery of the entire region from a post-disaster state, coordinate rebuilding efforts using a build back better philosophy and enhance community-level resiliency." "186

It is important to note two examples of "non-emergency" laws that take on heightened importance during disaster recovery. First, environmental, health, and safety concerns are of particular salience. Communities are vulnerable, not only to the direct harm from a disaster, but also increased risks in its aftermath. Air and water quality, for example, were significant concerns in the aftermath of the Fort McMurray wildfire. Air quality in the region was compromised by particulate matter and potential toxins (ozone, heavy metals, refrigerants) released from burnt buildings, industrial sites, cars, and the forest. Water treatment was disrupted during the fire, leading to concerns about whether drinking water was safe to consume. ${ }^{187}$ Recovery crews had to remove layers of ash to ensure that contaminants in the ash were not transferred into the soil. ${ }^{188}$ Recovery also requires significant demolition and reconstruction activities, bringing with it an influx of workers in construction and related fields. ${ }^{189}$ These recovery activities are governed by provincial environmental laws ${ }^{190}$ and occupational health and safety laws. ${ }^{191}$

Yet the connection between these laws that operate at all times and disaster law is not always clear. A significant finding of the post-fire assessment was that it was unclear during a state of emergency which provincial departments "had the legislative authority to make decisions regarding the appropriate health and safety thresholds for re-entry, particularly for water safety, air quality and other potential hazards to public health."192 Yet, the need for close environmental monitoring and testing and any resulting environmental advisories during the immediate recovery period of a disaster is entirely foreseeable. Accordingly, the delineation of the roles and responsibilities of relevant departments and decision-makers during the recovery period ought to be determined in advance. Similarly, need for expedited

OIC 109/2016, (Emergency Management Act).

Regional Municipality of Wood Buffalo, by-law No 16/013, Consolidated Version of Wood Buffalo Recovery Committee Bylaw (23 June 2016).

RMWB, Recovery Plan, supra note 108 at 13.

Government of Alberta, "Environmental Monitoring in Fort McMurray," online: $<$ https://www.alberta. ca/environmental-monitoring-fort-mcmurray.aspx\#water $>$. See generally Potable Water Regulation, Alta Reg 277/2003, s 6.

Government of Alberta, "Fort McMurray Burned and Unburned Soil Samples"(Edmonton: Government of Alberta, 2016), online: < https://www.alberta.ca/documents/FtMcMurray-SoilMonitoringDataMemo. pdf $>$.

RMWB, Recovery Plan, supra note 108 at 29.

Environmental Protection and Enhancement Act, RSA 2000, c E-12, s 14 (requirement to develop ambient environmental quality objectives such as: Government of Alberta, "Alberta Ambient Air Quality Objectives and Guidelines Summary,” Air Policy, 2016, No 2); Potable Water Regulation, supra note $187, \mathrm{~s} 6$ (on mandatory quality standards for drinking water).

Occupational Health and Safety Act, RSA 2000, c O-2.

KPMG LLP, supra note 22 at 46. 
demolition and rebuilding after a disaster is entirely foreseeable. Thus, the connection between occupational health and safety laws and emergency law also ought to be clear.

As communities shift from short-term to long-term recovery, the focus also shifts from immediate post-disaster risks to how to build the community so it is resilient to future disasters. This engages the second set of vital "non-emergency" laws: planning and development laws, which will impact whether a community builds back better. Contemporary disaster research emphasizes the importance of the connection between its recovery and prevention stages. The heightened public awareness of disasters during the recovery stage often creates the opportunity for significant legal and policy change to enhance prevention and mitigation. ${ }^{193}$ While early disaster research and practice focused on the connection between preparedness and response, current research instructs that recovery and prevention are critical moments for ameliorating community vulnerability and thus realizing the goal of building back better. ${ }^{194}$

In the EM Framework, the federal government, provinces, and territories have committed to a principle of building back better during the recovery phase of the disaster cycle. ${ }^{195}$ Building back better is a now ubiquitous concept in disaster management that highlights the "need to place environmental hazards within the wider contexts of building sustainable communities and not re-creating or exacerbating vulnerabilities." ${ }^{196}$ Building back better bridges recovery efforts with mitigation.

In the context of the Beast, however, building back better is not reflected in any specific legal requirements. The governments of Alberta and Canada have, thus far, taken a very light touch to building back better, offering financial incentives (or creating disincentives). The federal DFAA Guidelines allow for additional funding to provinces for projects that contain mitigation enhancements to reduce vulnerability to future disasters. ${ }^{197}$ This allows provinces to receive slightly more than the baseline replacement cost of damaged or destroyed infrastructure. In the aftermath of the southern Alberta flooding in 2013, the province amended legislation to allow for the promulgation of regulations prohibiting development in floodways. ${ }^{198}$ However, no regulations have been promulgated, and Fort McMurray was intended to be exempt in any event. ${ }^{199}$ Despite one of the heavily-damaged Fort McMurray neighbourhoods being located in a flood zone, the province does not appear to have implemented any measures to prohibit or discourage development in this area. ${ }^{200}$

The philosophy of building back better is closely tied into the broad network of municipal planning and development laws. After temporarily prohibiting redevelopment in heavily-

Olshansky \& Chang, supra note 72 at 201.

Ibid. See also Jane C Ingram et al, "Post-Disaster Recovery Dilemmas: Challenges in Balancing Shortterm and Long-term Needs for Vulnerability Reduction" (2006) 9:7 Environmental Science \& Policy 607. The importance of recovery is acknowledged in EM Framework, supra note 8 at 8. EM Framework, ibid.

Jim Kennedy et al, "The Meaning of 'Build Back Better': Evidence From Post-Tsunami Aceh and Sri Lanka" (2008) 16:1 J Contingencies \& Crisis Management 24 at 25.

Supra note 179 at 3.3 .

Municipal Government Act, RSA 2000, c M-26, s 693.1.

Alberta Municipal Affairs, "Overview of Bill 27, Floodway Development Regulation Consultation" (Edmonton: Municipal Affairs, 2014), online: <www.municipalaffairs.alberta.ca/1934>.

Government of Alberta, Home Again, supra note 17 at 41. 
affected areas (due to health and safety concerns), ${ }^{201}$ the municipality began issuing the necessary permits to restore destroyed and damaged infrastructure in the city. As of 3 November 2017, the municipality had conducted nearly 2,600 demolition inspections, approved 1,057 development permits (a prerequisite for reconstruction), and approved 1,183 building permits. ${ }^{202}$ However, there is nothing in the municipality's recovery plan indicating that municipal bylaws had been amended to modify rebuilding requirements to mitigate future disaster risk. ${ }^{203}$ Indeed, the post-fire assessment identified the need for provincial and local disaster resilience strategies that would ensure that recovery and rebuilding occurs in a manner that reduces future disaster risk. ${ }^{204}$

Current disaster law focuses on providing adequate compensation for those who have suffered disaster harm or loss, raising important questions about distributional justice in the aftermath of a disaster. This body of disaster recovery law is essentially retrospective. Forward-looking laws, such as the "ordinary" (that is, non-emergency) planning and development laws, are crucial to ensuring that communities can build back better and reduce their vulnerability to future disaster harm. In the instance of the Beast, however, there appear to be no legal mechanisms that link disaster recovery with the high-level commitment of provincial and federal governments to the principle of building back better.

\section{The Law Of Disaster Prevention and Mitigation}

As just noted, a vulnerability perspective identifies the juncture between recovery and prevention as a critical moment for building back better in order to reduce future vulnerability. In order to be impactful, prevention must begin to target the underlying systemic drivers of disaster vulnerability. As we have seen, the focus of the building back better philosophy is often on the reconstruction of physical infrastructure to reduce risk to future disasters. However, building back better can and ought to apply to our civic infrastructure too: that is, addressing the limits and gaps in existing law and policy that have contributed to disaster vulnerability. The challenge, then, is to begin to imagine legal mechanisms that can channel recovery and prevention measures in a direction that begins to address systemic drivers of vulnerability. As we will see, the Beast represents a missed opportunity to connect recovery and prevention to systemic drivers, as prevention has been defined in an unduly narrow fashion.

In its current form in Canada, it is possible to identify four components of the law of disaster prevention: (1) continuous learning; (2) mainstreaming disaster risk reduction; (3) public awareness; and (4) targeted mitigation infrastructure. As we will now see, however, these components are largely in the form of policy objectives and there are few legislated or regulatory provisions that operationalize these goals.

Regional Municipality of Wood Buffalo, by-law No 16/011, To Amend the Law Use Bylaw by Temporarily Restricting Development in Certain Areas of the Municipality (28 June 2016). Regional Municipality of Wood Buffalo, "Recovery Task Force - Rebuild Pillar Progress Update," online: <www.rmwb.ca/News-Room/RMWB-Wildfire-Information/Recovery-Progress-Updates/Re build-Pillar-Progress.htm>.

RMWB, Recovery Plan, supra note 108. Bylaw No 16/020 amended the Land Use Bylaw for areas affected by the wildfire in order to provide additional rebuilding options and to streamline the permitting process: Regional Municipality of Wood Buffalo, by-law No 16/020, To Amend Land Use Bylaw No 99/059, (28 September 2016).

KPMG LLP, supra note 22 at 53. 
The first aspect of disaster recovery law is a commitment to continual learning through post-disaster assessment. Alberta's hazard-specific wildfire plan includes a standard requirement that each organization involved in the fire conduct a post-incident assessment to identify the causes of the fire, effectiveness of response, and strategies to prevent or mitigate future fires. ${ }^{205}$

The Alberta government has developed a practice of arranging for comprehensive, external assessments after major disasters. This practice was maintained in the instance of the Beast following analogous assessments of the 2011 Lesser Slave Lake wildfire and the 2013 flooding in southern Alberta. The comprehensive post-fire assessment revealed several strengths of the provincial response (for example, enhanced support for local communities, and the upgraded Emergency Alert system) ${ }^{206}$ but also revealed that the provincial government had failed to incorporate many of the recommendations made after the Lesser Slake Lake fire, including establishing a provincial evacuation framework, enhancing emergency communications, and formalizing procedures for the Provincial Operations Centre. ${ }^{207}$ In light of the lack of transparency in emergency preparedness, these external assessments serve an important role in public accountability by revealing to the public gaps and flaws in otherwise opaque and technical disaster management practices.

One first step in strengthening Canadian disaster law is to formalize the Alberta government's practice of seeking an external post-disaster assessment. Making this a requirement in the EMA (Alta) would entrench the government's commitment to continual learning as part of disaster prevention. While there is often significant political pressure in the aftermath of an emergency response that can lead to the government commissioning an assessment, a legal requirement will remove any uncertainty from this process. Indeed, a vulnerability perspective reveals the importance of formalizing this requirement because it highlights the disproportionate disaster harm suffered by marginalized groups. These are often the same groups who are the least able to exert influence in the political process. They therefore may not be able to generate the necessary public pressure to demand an external assessment when others are relatively unaffected by the event. One need look no further than the chronic and repeated states of emergency for reserves across Canada as evidence of this problem. $^{208}$

Moreover, in light of the important role that external assessment currently plays in public accountability - by spotlighting otherwise opaque emergency management practices such a legal requirement should not be exclusive to major disasters. Indeed, it is possible to imagine federal leadership in this respect by linking external assessment of provincial practices to federal assistance. The EMA (Canada) could make commissioning an external assessment a condition of a province's receiving federal support under the Act. Such a requirement would encourage best practices at the provincial and local levels with the goal of reducing future vulnerability (and thus reliance on future federal disaster relief funding).

\footnotetext{
$205 \quad$ Ibid at 15.

206 Ibid at 5-6 (summary).

$207 \quad$ Ibid at $66,79,90$.

208 See e.g. Allan Woods, "A First Nations Cry for Help Gets Little Government Attention: Star Investigation,” Toronto Star (25 April 2016), online: <https:/www.thestar.com/news/canada/2016/04/ 25/a-first-nations-cry-for-help-gets-little-government-attention-star-investigation.html $>$.
} 
The second and third features of mainstreaming disaster risk and public awareness are expressed in Canada's National Disaster Mitigation Strategy, an intergovernmental strategy between the federal government and the provinces and territories. ${ }^{209}$ The Mitigation Strategy sets out several high-level commitments, with special attention to "reducing risk posed by natural hazards." 210 In the Mitigation Strategy, governments agree to promote the mainstreaming of disaster risk reduction initiatives into existing public programs. They also agree to promote disaster prevention and mitigation public awareness. They further agree to promote scientific and engineering best practices and lessons learned for sustainable and cost-effective mitigation.

Federal government action in these three areas of commitment has been relatively minimal. ${ }^{211}$ In terms of mainstreaming prevention and mitigation, Public Safety Canada has developed a Platform for Disaster Risk Reduction, a program which brings together hundreds of organizations through its annual roundtable, for the purpose of discussing national disaster risk reduction issues and sharing information. ${ }^{212}$ In addition, Public Safety Canada maintains a natural hazards database, ${ }^{213}$ but there is little additional visible action being taken to promote public awareness of a range of disasters at the national level. As already noted, the federal government incentivizes prevention and mitigation infrastructure through its $D F A A$. Notably, the federal government also launched a specific program, the National Disaster Mitigation Program, which targets flood risk and flooding and includes a number of initiatives that address these three areas of disaster prevention and mitigation. ${ }^{214}$

The EMA (Alta) empowers the Minister to "conduct public information programs relating to emergency preparedness for and the mitigation of disasters." ${ }^{215} \mathrm{With}$ respect to wildfire specifically, this is implemented through the Alberta FireSmart program. ${ }^{216}$ The program contains seven disciplines, including public education, firefighter training, interagency cooperation, and fuel management. ${ }^{217}$ The significance of fuel management is emphasized by the hazard-specific Interface Fires plan, which sets out requirements for removing low-lying shrubs and maintaining firebreaks around man-made structures. ${ }^{218}$

FireSmart principles are again emphasized as a specific mitigation activity in Wood Buffalo's Recovery Plan. The municipality anticipates conducting a wide-ranging review of

Government of Canada, Canada's National Disaster Mitigation Strategy (Ottawa: Government of Canada, 2011), online: <https://www.publicsafety.gc.ca/cnt/rsrcs/pblctns/mtgtn-strtgy/mtgtn-strtgyeng.pdf $>$ [Mitigation Strategy]. Pursuant to EMA (Canada), supra note 79, s 4(1)(f).

Mitigation Strategy, ibid at 1 .

The Infrastructure Canada database (dating back to 2002) only includes one project categorized as "disaster mitigation." One program, the Joint Emergency Preparedness Program, identified as a commitment in the strategy, appears to have been scrapped: Federation of Canadian Municipalities, "Emergency Preparedness and Response" (28 August 2017), online: <https://fcm.ca/home/issues/ emergency-preparedness-and-response.htm>.

"Canada's Platform for Disaster Risk Reduction" (Ottawa: PSC, 2017), online: <https://www.public safety.gc.ca/cnt/mrgnc-mngmnt/dsstr-prvntn-mtgtn/pltfrm-dsstr-rsk-rdctn/index-en.aspx $>$. The Platform and its Advisory Committee also facilitates members joining more specific working groups on disaster risk reduction.

"Natural Hazards of Canada"(Ottawa: PSC, 2015), online: $<$ https://www.publicsafety.gc.ca/cnt/mrgncmngmnt/ntrl-hzrds/index-en.aspx>.

Public Safety Canada, "National Disaster Mitigation Program (NDMP)" (Ottawa: PSC, 2017), online:

$<$ https://www.publicsafety.gc.ca/cnt/mrgnc-mngmnt/dsstr-prvntn-mtgtn/ndmp/index-en.aspx $>$.

Supra note 93, s 9(g).

Government of Alberta, Home Again, supra note 17 at 40-41.

Ibid at 40 .

Supra note 99 at $7-8$. 
all its development bylaws to ensure they comply with FireSmart principles. ${ }^{219}$ In addition to this example of mainstreaming disaster risk reduction, the Recovery Plan also includes targeted mitigation projects that provide multiple evacuation routes out of the region in the event of a future disaster. ${ }^{220}$

A second preliminary step for strengthening the law of disaster prevention and mitigation is to require governments to engage in prevention practices that directly address systemic drivers of disasters. Existing Canadian disaster law appears to implement disaster recovery and prevention mechanisms in a remarkably narrow fashion that fails to connect recovery with systemic risk factors in any robust way.

For example, the centerpiece of prevention is better implementation of FireSmart policy at the municipal and provincial levels. ${ }^{221}$ FireSmart is a program that encourages greater public awareness of fire hazards, better training of firefighters, and promotes fuel management (for example, the maintenance of firebreaks around buildings). While FireSmart may adequately address some immediate contributors to future fire risk - the growing interaction between humans and forested areas, for example — it does not address deeper, more systemic drivers of disaster vulnerability, such as land-use planning and rapid urbanization.

One example of an underlying driver is the rapid population growth of the Fort McMurray region due to oil sands development. ${ }^{222}$ The post-fire assessment rightly identifies the need for alternate evacuation routes to accommodate the city's large population. ${ }^{223}$ But, in addition to this physical infrastructure, it is worth examining the deficiencies in existing planning law that failed to identify this need in advance of a major disaster. Environmental law research has long identified the need for more robust environmental impact assessment that accounts for cumulative environmental impacts of development. ${ }^{224}$ Commentators have frequently pointed to the Alberta oil sands as an example of a region in which the absence of cumulative impacts assessment has allowed development in the region to grow unchecked by mounting environmental concerns. ${ }^{225}$

RMWB, Recovery Plan, supra note 108 at 46-47.

Ibid at 35 .

Government of Alberta, Home Again, supra note 17 at 40; RMWB, Recovery Plan, ibid at 18, 35; KPMG LLP, supra note 22 at 49-50; MNP LLP, A Review of the 2016 Horse River Wildfire: Alberta Agriculture and Forestry Preparedness and Response (Edmonton: MNP LLP, 2017) at 48-49, online: $<$ https:/www.alberta.ca/assets/documents/Wildfire-MNP-Report.pdf $>$.

Cutter, Boruff \& Shirley, supra note 51 at 248; Lisa Grow Sun, "Smart Growth in Dumb Places: Sustainability, Disaster, and the Future of the American City" [2011] 6 BYUL Rev 2157 at 2157. KPMG LLP, supra note 22 at 66.

Martin ZP Olszynski, “Ancient Maxim, Modern Problems: De Minimis, Cumulative Environmental Effects and Risk-Based Regulation" (2015) 40:2 Queen's LJ 705 at 727; Thomas R Berger, Northern Frontier, Northern Homeland: The Report of the Mackenzie Valley Pipeline Inquiry, vol 1 (Ottawa: Supply and Services Canada, 1977) (remains the gold standard for robust and inclusive assessment). Commissioner of the Environment and Sustainable Development, 2011 October Report of the Commissioner of the Environment and Sustainable Development: Chapter 2-Assessing Cumulative Environmental Effects of Oil Sands Projects (Ottawa: Auditor General of Canada, 2011), online: $<$ www. oag-bvg.gc.ca/internet/English/parl_cesd_201110_02_e 35761.html >; Heather McLeod-Kilmurray \& Gavin Smith, "Unsustainable Development in Canada: Environmental Assessment, Cost-Benefit Analysis, and Environmental Justice in the Tar Sands" (2010) 21 J Envtl L \& Prac 65. See also Shaun Fluker, "The Jurisdiction of Alberta's Energy and Utilities Board to Consider Broad Socio-Ecological Concerns Associated with Energy Projects" (2005) 42:4 Alta L Rev 1085 (on gaps in assessing the socio-economic impacts of rapid development). 
In the context of disaster prevention, one can imagine a logical extension of known, if not implemented, cumulative environmental assessment processes to account for disaster risk. Environmental assessment law might require that region-based or project-based assessments account for the increased disaster risk created by growing a region's population. This allows proper mitigation measures (such as additional evacuation routes) to be identified and implemented as the community grows and, hopefully, before a disaster occurs.

Relatedly, the independent post-fire report recommended that the provincial government develop and utilize a planning tool to address the multi-faceted nature of major disasters. It identified the need for an annual cumulative risk assessment to enable the province to plan for large-scale disasters. ${ }^{226}$ It noted the province's current inadequate focus on hazardspecific planning that "may contribute to a lack of understanding of the collective risk that a wildfire or other disaster may bring about." ${ }^{227}$ A cumulative risk assessment would enable the province and local governments to better determine whether they have adequate capacity to respond.

Of course it is a fallacy to think that disaster law can prevent or mitigate all disasters. The challenge for disaster law is rather to devise institutions and procedures that help us expect the unexpected while simultaneously addressing the root causes of vulnerability. The institutional responses to the Fort McMurray wildfire reveal that, at present, there are glaring ways in which Canadian disaster law fails to do either.

Recovery efforts in the aftermath of the Beast have been comprehensive and will continue for years as the community rebuilds after this major event. These recovery efforts include initiatives at the federal, provincial, and local level that seek to promote continual learning, mainstream disaster risk reduction, enhance public awareness, and promote targeted mitigation projects. However, most of these initiatives are ad hoc programs and projects that are not mandated by the formal structure of current Canadian disaster law.

This part has mapped the terrain of Canadian disaster law. It has identified key characteristics of Canadian disaster law at each of the four stages of the disaster cycle. In doing so, it has also identified striking ways in which disaster law departs from the core insights of a vulnerability perspective. In particular, this part noted the absence of a focus on people and communities in the law of emergency preparedness, which instead focused more on technical concerns about hazards, assets, and services. In addition, it noted the failure of disaster law to formalize connections between disaster recovery and prevention in order to address systemic drivers of disaster risk and reduce future vulnerability.

Ibid at 62. Particularly striking, in light of the heavy industrialization of the municipal region, is the current gap in emergency planning with respect to identifying industry infrastructure such as pipelines and communications towers (ibid). 


\section{CONCLuSion}

This article has mapped the landscape of Canadian disaster law. It has argued that the need to analyze disaster law arises clearly from the central role that law plays in both creating and ameliorating conditions of disaster vulnerability. Disaster research no longer conceptualizes disasters as natural events. Rather, they are sociological phenomena in which law operates long before and long after the extreme event and its immediate aftermath to shape environmental and social conditions that lead to disaster harm. Moreover, it has argued that vulnerability is an analytically useful perspective because it captures the universal, individual, and relational dimensions of disasters. It thus demands that disaster law take a context-sensitive approach by attending to individuals and communities who are especially vulnerable to disasters.

The article has identified the shared, structural characteristics of the federal, provincial, and local emergency laws that were implicated in the Fort McMurray wildfire. It has noted gaps and challenges with current law at all four stages of the disaster cycle. First, the law of disaster preparedness includes standard features of emergency management legislation, a specialized public institution, a central emergency plan, and an operations centre. However, the emergency plan and secondary plans, crucial elements of emergency preparedness, are not transparent. This means that the public is not able to scrutinize the adequacy of disaster preparedness. Moreover, the publicly available sources suggest that the law of disaster preparedness does not identify or attend to vulnerable communities in any concrete way. Rather than focusing on the necessarily place-based and context-specific factors that create or contribute to a community's vulnerability, the law of disaster preparedness relies on a uniform and one-dimensional concept of vulnerability.

Second, the law of disaster response is characterized by the legislated delegation of power to declare states of emergency and a predetermined set of emergency response powers. In contrast to the other three stages of the disaster cycle, this aspect of disaster law is relatively clear and coherent. Yet the response to the Beast suggests that coordination between levels of government during large-scale disaster response remains a challenge.

Third, the law of disaster recovery contains compensatory and planning and development dimensions. The article has noted that while compensation for disaster harm is an area that has received some attention in the legal literature, climate-related disasters pose fundamental challenges for the policy and institutional design of insurance, liability, and public disaster relief funds. The article has drawn attention to the significance of "non-emergency" planning and development laws in disaster recovery. It noted that in the context of the Beast, these laws are not clearly and explicitly connected to disaster recovery law, which undermines their potential for reducing future vulnerability by building back better.

Finally, within the law of disaster prevention, it is possible to observe the four components of continual learning, mainstreaming disaster risk reduction, public awareness, and targeted mitigation projects. A vulnerability perspective emphasizes the crucial connection between recovery and prevention for confronting systemic drivers of disaster vulnerability. This article has highlighted the extent to which these prevention mechanisms are underdeveloped in Canadian law. It has also observed that the mechanisms that do exist are implemented in a narrow manner that fails to address underlying drivers of disaster vulnerability. In sum, the 
terrain of Canadian disaster law does not reflect the multi-dimensional understanding of vulnerability found in disaster literature, and thus leaves communities unnecessarily susceptible to disaster harm.

The independent assessment of the Fort McMurray wildfire attributed the success of the response "to the young demographics of the community, and how the community rallied together to help one another evacuate safely." ${ }^{228}$ From this conclusion, it is easy to surmise that the outcome was a product of "blind luck." ${ }^{229}$ This impression resonates with the major gaps this article has uncovered in Canadian disaster law. It evidences the urgent need to seriously integrate disaster research into existing laws and policies to ensure that Canadians are not unnecessarily vulnerable to disaster harm. In the absence of these changes, communities that are less able-bodied, less affluent, and less cohesive face the prospect of disaster harm.

The observation about luck is dangerous, however, because it risks underestimating the tangible ways in which communities can, through their laws and institutional practices, protect themselves from disaster harm. A vulnerability perspective suggests that what may appear to be luck is often the product of less visible institutional practices - for example, sound building codes, stable local economies, and universal health care. In this respect, Fort McMurray reflects a paradigmatic disaster double bind. The oil sands' heartland is a contributor to the community's young, able-bodied, and affluent demographics that allowed the community to avoid a worst-case scenario. But it is also the reason why so large a community is in the middle of harm's way.

A research agenda on Canadian disaster law must unpack the roles that law plays in creating disaster double binds, like that experienced in Fort McMurray. As this article has argued, law inevitably governs disasters. The challenge is ensuring that it operates to reduce disaster vulnerability. Without attending to both the immediate and systemic ways in which law contributes to conditions of vulnerability, disaster law can only ever play a partial, and inadequate, role in disaster management.

Jason Markusoff, "Why Fort McMurray Residents were the Real Heroes of the Fire Crisis," Macleans (9 June 2017), online: $<$ www.macleans.ca/news/why-fort-mcmurray-residents-not-authorities-were-thereal-heroes-of-the-fire-crisis/>. 
[this page is intentionally blank] 